\title{
HABITAR RUÍNAS \\ O BAIRRO DA 28 (CENTRO HISTÓRICO DE SALVADOR) NAS MEMÓRIAS DE SEUS HABITANTES
}

\section{Urpi Montoya Uriarte ${ }^{1}$}

\section{Palavras iniciais sobre as mulheres da 28 e suas memórias}

Este artigo apresenta uma seleção de trechos das memórias de 10 moradoras $^{2}$ do antigo bairro da 28 e reflete sobre o enorme contraste entre, de um lado, a fama de um bairro arruinado, composto de casarões mal conservados, encortiçados e pobres, e, do outro, as lembranças de um bairro que não priorizam cenas ou situações de fome, dificuldades, padecimentos, sofrimentos ou precariedade das instalações, nem a estreiteza dos quartos ou periculosidade dos imóveis, mas as histórias de um bairro vivo, cheio de moradores e gente de fora, com ruas animadas pelo comércio variado e intenso, localizado no andar térreo de seus casarões. Trata-se de memórias antropocentradas, que falam o tempo todo de gente de fora e gente de dentro do bairro, gente estranha e gente conhecida, gente vivendo e sobrevivendo, gente comercializando e mercando. Os de fora são lembrados em sua quantidade, diversidade e presença anônima; e os de dentro, pelos laços próximos de amizade, solidariedade, ludicidade e, também, conflitos e desentendimentos.

Nosso objetivo ao expor esta visão do bairro contida nas memórias das moradoras antigas da 28 não é exaltar um modo de vida desaparecido, nem afirmar a veracidade de suas lembranças. Não queremos entrar na discussão de estarmos ou não diante de memórias nostálgicas ou anacrónicas. A Antropologia expõe - ou deveria expor pensamentos para provocar outros pensamentos. O etnógrafo entra - ou deveria entrar - no pensamento do Outro, não para qualificá-lo ou verificá-lo, mas para entender conceitos e experimentar com eles. Nas palavras de Eduardo Viveiros de Castro (2002: 129), não se trata "de explicar, interpretar, contextualizar, racionalizar esse pensamento", mas "utilizar, tirar suas consequências, verificar os efeitos que ele pode produzir no nosso".

\footnotetext{
${ }^{1}$ Universidade Federal da Bahia (UFBA), Brasil. E-mail: urpi@ terra.com.br. ORCID: https://orcid.org/00000002-8135-7559

${ }^{2}$ Devido ao expressivo número de mulheres no grupo, usaremos principalmente o gênero feminino para nos referirmos à totalidade dos e das interlocutoras.
} 
Desta perspectiva, é epistemologicamente incorreto qualificar esta ou quaisquer outras memórias de falsas, ilusórias, romantizadas, fantasiadas ou exageradas, pois não existem memórias verdadeiras ou objetivas. Não se trata de limpar, enxugar ou extrair das memórias alguma verdade, pois, mais do que documentos sobre o passado, elas são filtros interpretativos do presente. Efetivamente, mais do que do passado, as memórias falam do presente.

O campo da memória é particularmente escorregadio. Diversos intelectuais (e, particularmente, os historiadores) nos alertam que é preciso levar em consideração que a memória omite - "o esquecimento é, em suma, a força viva da memória e a lembrança é o produto desta" (Augé, 2008: 28, tradução nossa). Que a história não pode se basear apenas na memória - "a história não sempre pode acreditar na memória" (Sarlo, 2007: 9, tradução nossa). Que ela é sempre uma reconstrução - “essa reconstrução se opera segundo linhas já demarcadas e delineadas por nossas outras lembranças ou pelas lembranças dos outros" (Halbwachs, 1990: 77). E que precisa passar pelo filtro dos historiadores, pois ela é “essencialmente mítica, deformada, anacrônica" (Le Goff, 1988: 194, tradução nossa). Em suma, estamos devidamente avisados de que é preciso desconfiar da memória, pois ela "pode se permitir o anacronismo, já que se compõe daquilo que o sujeito se permite ou consegue lembrar, do que ele esquece, cala intencionalmente, modifica, inventa (...)" (Sarlo, 2007: 81, tradução nossa). Entretanto, nosso intuito nestas páginas não é fazer a história da 28, algo que nos levaria necessariamente a cotejar diversas fontes, dentre as quais as memórias, nem entrar no debate no interior da disciplina da história sobre os méritos da memória como fonte.

O que nos propomos aqui é levar as memórias a sério, da mesma forma que o trabalho do antropólogo leva a sério a palavra nativa. Não são "apenas" memórias. Ou memórias que precisam ser tomadas com cautela devido à carga emocional. Ou memórias distantes do "real". Ou miragens que deturpam a realidade. São formas de ver o passado que dizem respeito tanto ao passado quanto ao presente e ao futuro.

As frases citadas neste artigo pertencem a Sandra, Pró Cida (Jecilda), Anastácia, Edna, Rita, Helena, Eugênia, Tânia, Cícero e Daniel, que chegaram ou cresceram na 28 entre as décadas de 1970 e 1980. Nos anos 1990, foram testemunhas do trágico desenrolar das primeiras etapas do Projeto de Recuperação do Centro Histórico de Salvador, que acontecia nas micro localidades vizinhas do Centro Histórico de Salvador (CHS) - Maciel, Pelourinho, Carmo, Passo -, onde viram seus amigos, parentes ou conhecidos serem expulsos até quase não ficar ninguém no que foram aquelas ruas apinhadas e 
movimentadas. Em finais daquela década, com a implementação da $7^{\mathrm{a}}$ etapa desse projeto, foi a vez delas viverem na própria carne as expulsões, arbitrariedades, desespero, desinformações e incertezas. Todavia, esta última etapa do projeto se deparou com moradores mais preparados para enfrentar a expulsão: em 2011, junto com outros vizinhos e aliados, nossas interlocutoras formaram e integraram a Associação de Moradores e Amigos do Centro Histórico (AMACH), cuja luta lhes garantiu, por meio da assinatura de um Termo de Ajustamento de Conduta (TAC) em 2005, o direito de permanência na área. No entanto, como veremos ao longo destas páginas, ganharam aos poucos o direito de uso das casas $^{3}$, mas perderam seu bairro.

As conversas com nossas interlocutoras aconteceram ao longo do semestre 2019.1 no âmbito da Ação Curricular em Comunidade e em Sociedade "Habitar casarões ocupados do centro de Salvador", sob a minha responsabilidade ${ }^{4}$. O objetivo dessa ACCS era produzir uma cartografia do bairro, produto que fora solicitado à equipe da ACCS um semestre antes, por ocasião de um trabalho pontual realizado com a AMACH para a identificação dos imóveis vazios ou em ruínas na sua área do CHS, conhecida como Sétima etapa ${ }^{5}$. Ao concluir as tarefas de identificação, geolocalização e registro fotográfico de cada um desses imóveis para a realização da cartografia dos imóveis vazios do $\mathrm{CHS}^{6}$, as lideranças Jecilda Mello e Sandra Santos nos solicitaram uma ACCS específica para sua área que produzisse uma cartografia do bairro de São Dâmaso. Intrigados com essa denominação e desafiados com essa temática, concordamos e iniciamos os trabalhos junto a 10 moradoras membros da $\mathrm{AMACH}$, um grupo com experiência em ACCS e parceria

\footnotetext{
${ }^{3}$ Trata-se de casas que não foram escolhidas por elas, que nem sempre eram compatíveis com o número de membros da unidade familiar e que apresentaram, desde o início, inúmeros problemas estruturais (ver Figueiredo et al., 2017).

4 "Ação Curricular em Comunidade e em Sociedade (ACCS) é um componente curricular, modalidade disciplina, de cursos de Graduação e de Pós-Graduação, com carga horária mínima de 17 (dezessete) horas semestrais, em que estudantes e professores da UFBA, em uma relação com grupos da sociedade, desenvolvem ações de extensão no âmbito da criação, tecnologia e inovação, promovendo o intercâmbio, a reelaboração e a produção de conhecimento sobre a realidade com perspectiva de transformação, conforme Resolução N N $^{\circ}$ 01/2013 do CONSEPE" (Disponível em: 〈https://proext.ufba.br/accs〉, acesso em 16 jun. 2020). A equipe que conformou esta ACCS estava formada por mim, pelos alunos e alunas regularmente matriculados no componente curricular e pelos alunos e alunas integrantes do Grupo de Pesquisa Panoramas Urbanos - Luísa Caria, Natalia Barreto, Marina Novaes e João Ritter -, todos da Universidade Federal da Bahia.

${ }^{5}$ Uso a grafia de Sétima etapa para me referir ao nome dado à área e $7^{\mathrm{a}}$ etapa para falar da fase específica do projeto de intervenção no CHS, que inclui as 8 ruas que formavam a 28 e uma parte da micro localidade da Ajuda.

${ }^{6}$ A cartografia produto da ACCS Habitar o Centro, em 2018.2 denomina-se o Mapa dos Vazios e Carcaças do Centro Histórico de Salvador. Disponível em www.panoramasurbanos.com.br.
} 
com a Universidade Federal da Bahia ${ }^{7}$. Resta frisar que o trabalho se realizou inteiramente nos locais em que estas mulheres se sentem à vontade: na sede de sua Cozinha Comunitária e nas ruas onde habitaram e permanecem até hoje.

Para produzir o mapa solicitado, a equipe teria de conhecer com profundidade o presente do bairro e com essa finalidade idealizamos os primeiros encontros no formato de rodas de conversa sobre este, as quais, pela abertura e flexibilidade próprias desta técnica, permitir-nos-iam conhecer os pontos que, para elas, eram importantes de serem falados e discutidos. Grande foi nossa surpresa ao detectar, desde o início destas rodas, o papel que o passado do bairro tinha para elas: ele monopolizava o tema dos encontros, era sempre trazido à tona por meio de lembranças das ruas movimentadas, dos personagens por todos conhecidos, dos incidentes que mobilizavam a comunidade, dos costumes partilhados pela coletividade etc. $\mathrm{O}$ tom destas lembranças era alegre e a intensidade desses tempos passados era revivida em forma de gargalhadas, falas simultâneas ou competição calorosa para obter a palavra.

Ao percebermos a importância e riqueza dessas lembranças, implementamos outra metodologia, que sucedeu às rodas de conversa: a equipe da ACCS se dividiu em duas subequipes e cada uma delas passou a receber, em cantos separados da Cozinha Comunitária, apenas duas interlocutoras, que eram colocadas na frente de um mapa vazio das 8 ruas que compõem a área, junto com canetas coloridas, gravador e filmadora. Enquanto uns perguntavam, outros preenchiam o mapa, outros filmavam e outros gravavam. As nossas interlocutoras narravam, com o maior detalhamento possível, onde e como eram os comércios, o lazer praticado, as instituições existentes, as atividades, festas, incidentes ou personagens que havia ou aconteciam em cada uma dessas ruas. Após a sessão de preenchimento do mapa, cada equipe saía pelas ruas do bairro com sua interlocutora, sempre gravando e filmando, para percorrer os locais narrados previamente, o que permitia reviver in locus as memórias apontadas no papel (cf. Figura 1).

\footnotetext{
7 A AMACH tem mantido uma relação próxima com a Faculdade de Arquitetura e Urbanismo da UFBA mediante a ACCS "Perícia Popular no Centro Histórico de Salvador", coordenada pela professora Glória Cecília Figueiredo, e os projetos de intercâmbio no âmbito da disciplina "Política, Democracia e Direito à Cidade”, ofertada pelo Programa de Pós-Graduação em Arquitetura e Urbanismo da UFBA, coordenada pela professora Ana Fernandes e o Grupo de Pesquisa Lugar Comum.
} 
Figura 1 - Momentos do trabalho da ACCS Habitar o Centro, 2019.1.
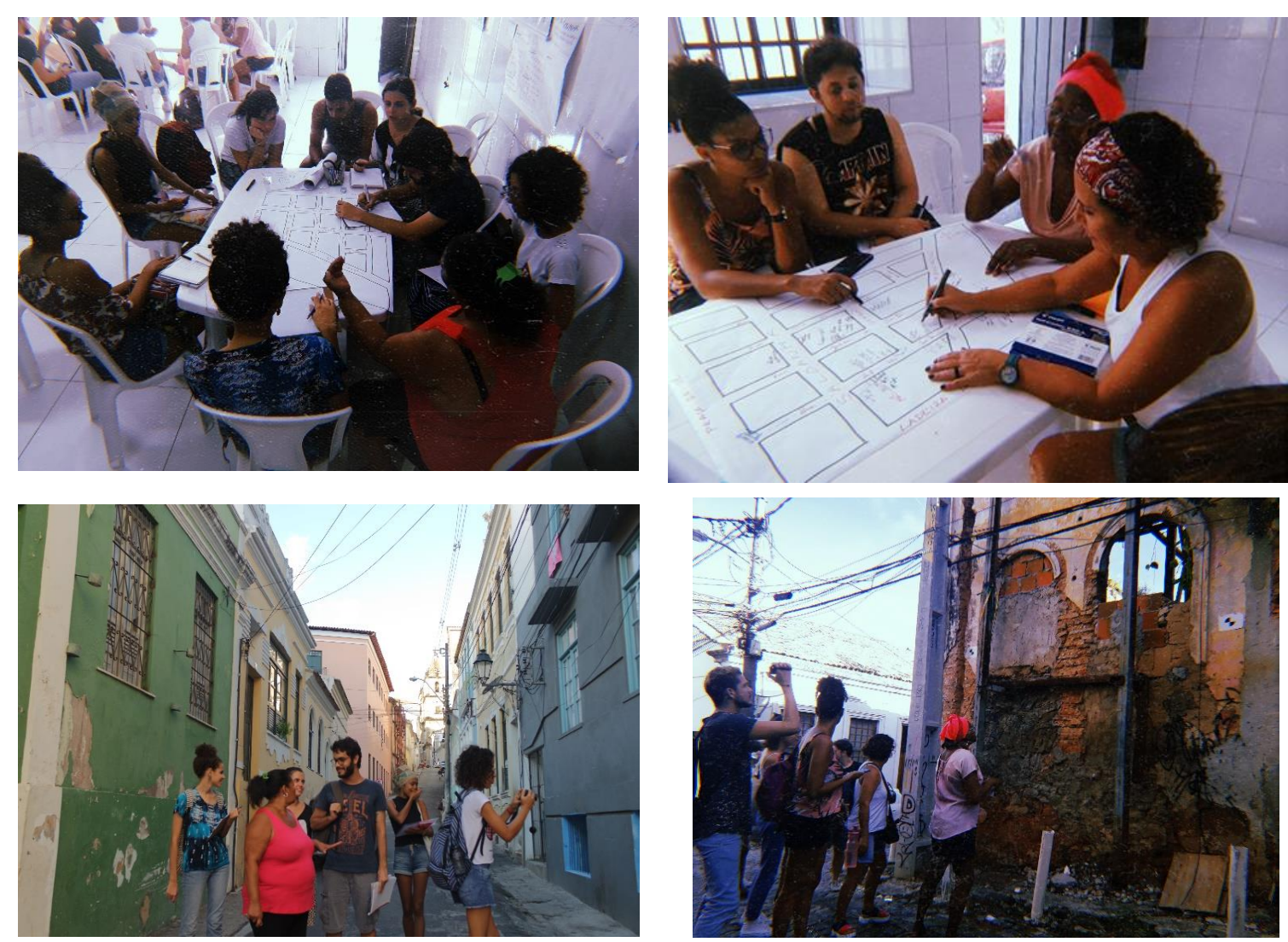

Fonte: Acervo ACCS/Panoramas Urbanos.

O resultado desta ACCS (2019.1) foi o mapa São Dâmaso: morte, vida $e$ (re)existência de um bairro ${ }^{8}$. Nestas linhas, tencionamos aprofundar as memórias que deram lugar ao mapa, escavando em alguns significados submersos que elas trazem à tona - bairro, casa, ruína - e refletindo sobre os discursos - sociológicos e patrimoniais - que estas contestam.

\section{Breve descrição do bairro da 28}

\footnotetext{
${ }^{8}$ Disponível em www.panoramasurbanos.com.br
} 
A 28 é uma micro localidade que deve seu nome à importância ou centralidade de uma de suas ruas, a Rua 28 de Setembro. Trata-se da área localizada entre a Ladeira da Praça, Praça da Sé, Baixa dos Sapateiros e Terreiro de Jesus.

Compõe-se de 8 ruas: Rua Saldanha da Gama, Rua da Oração, Rua do Bispo, Beco do Seminário, Rua Três de Maio, Rua São Francisco, Rua Guedes de Brito e Rua 28 de Setembro (antiga Rua do Tijolo). Junto com outras micro localidades, a 28 constitui a poligonal do CHS (cf. Figura 2), tombada em 1985 pelo Instituto do Patrimônio Histórico e Artístico Nacional (IPHAN).

Figura 2 - Micro localidades no interior da poligonal do Centro Histórico de Salvador.

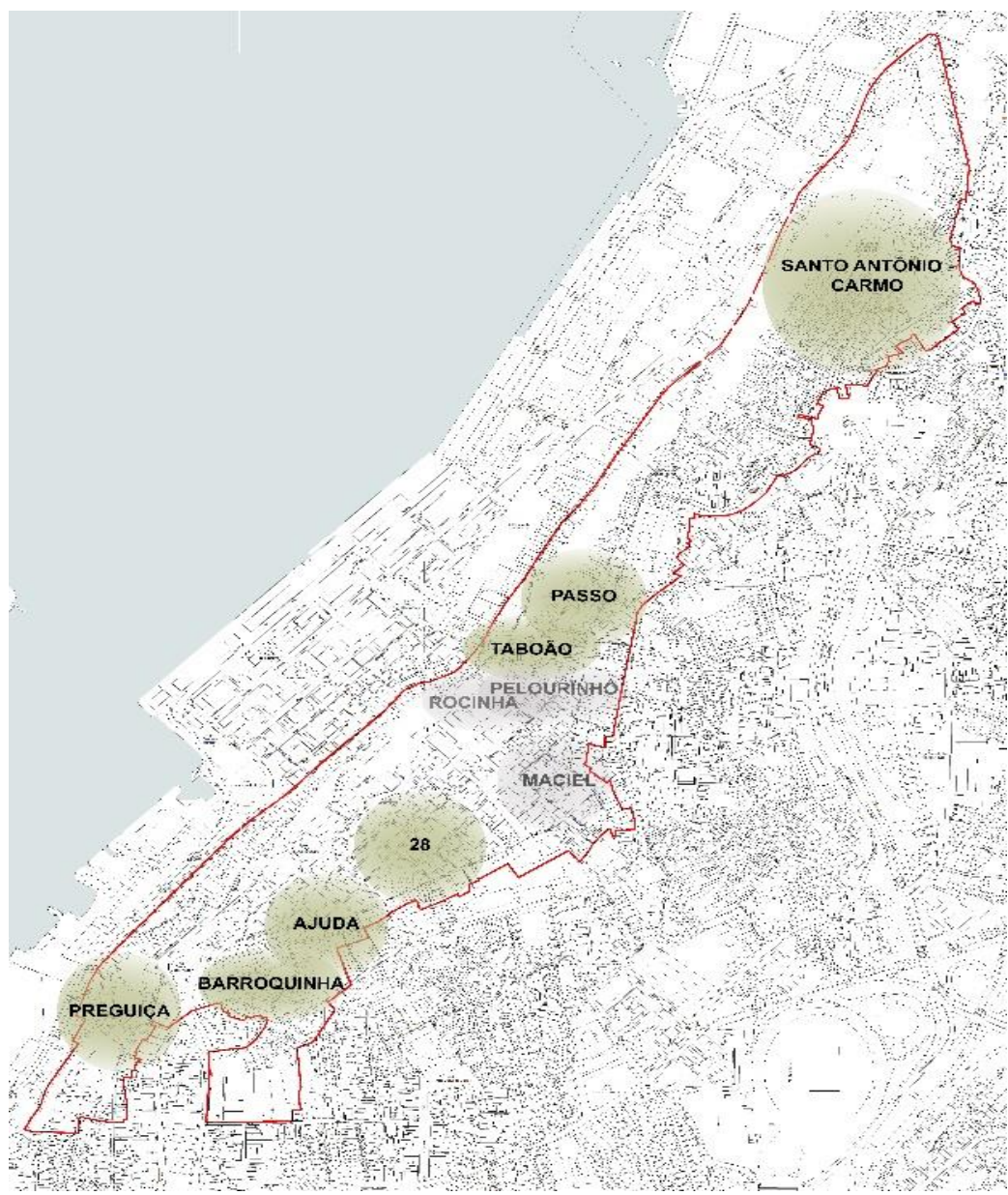

Fonte: Elaboração de Marina Novaes (ACCS/Panoramas Urbanos).

Repare o leitor que usamos o termo micro localidade (e não bairro) para apontar apenas uma delimitação geográfica, que nada diz respeito a suas características sociológicas. A micro localidade se torna bairro, comunidade ou simplesmente área em função de como seus habitantes concebem sua forma de habitar o espaço. O Maciel de antigamente e a Preguiça de hoje, por exemplo, chamam-se a si mesmas de comunidade, 
priorizando nesta autopercepção o tipo de relações estabelecidas entre seus habitantes relações de igualdade (Montoya Uriarte, 2019). Já os habitantes da 28 chamam sua área de bairro, priorizando, como veremos em diante, o caráter público de suas ruas.

Em contraste com as demais micro localidades do centro, o bairro da 28 não possui um único nome consensual ou permanente ao longo do tempo: para uns, ela era a 28; para outros, apenas Centro ou Centro Histórico; para a imprensa, trata-se até hoje da Cracolândia, e, para o Governo do Estado, ela é a Sétima etapa. A 28 foi, contudo, o nome mais usado pelas nossas interlocutoras para se referir a esta área-bairro.

Figura 3 - Rua Laranjeiras (Maciel) em finais da década de 1970.

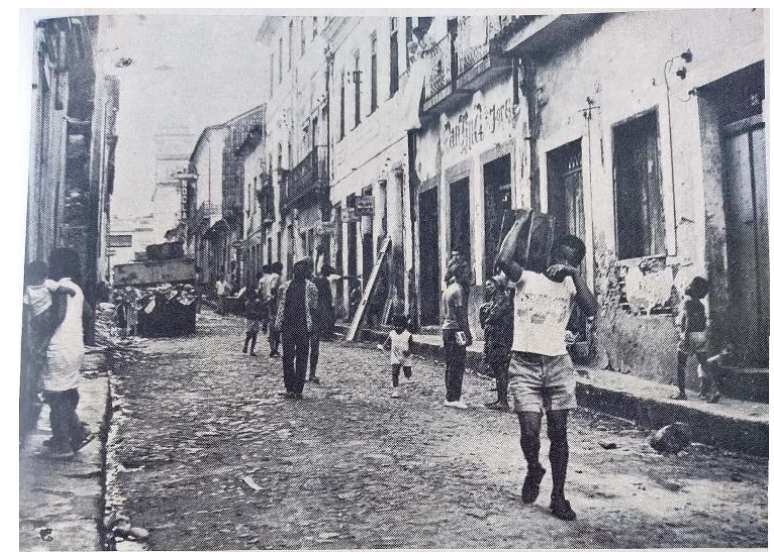

Fonte: Espinheira, 1971: 41.

Figura 4 - Rua São Francisco em 2019

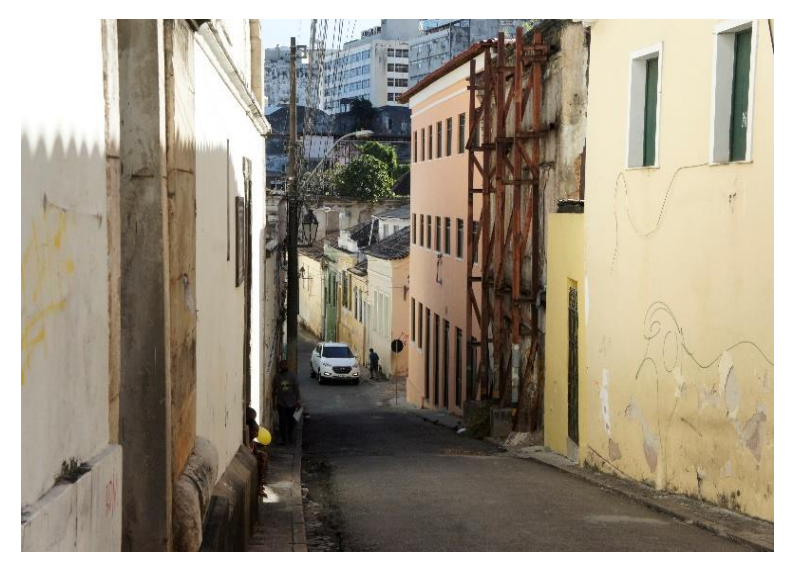

Fonte: Acervo ACCS/Panoramas Urbanos.

As ruas da 28, como as do antigo Maciel (cf. Figura 3), eram muito movimentadas, mas, em contraste com as segundas, as primeiras eram usadas e frequentadas tanto por habitantes, que moravam nos andares superiores dos velhos casarões, quanto por 
transeuntes, atraídos pela quantidade e diversidade de pequenos comércios localizados nos térreos dos casarões. Hoje, as ruas da 28 estão visivelmente esvaziadas, servindo mais aos carros do que às pessoas (cf. Figura 4). Com efeito, o bairro se tornou um grande estacionamento ao ar livre para o comércio localizado em seus arredores e não mais em seu interior. Tornou-se também, pelo grande número de escombros e casarões fechados, local de consumo de um grande número de usuários de drogas em busca de ruas ou cantos sem movimento 9 .

A $7^{\text {a }}$ etapa da reforma do CHS, iniciada em finais da década de 1990, é um demarcador de águas para este bairro. Antes da reforma, a área servia de moradia para 1.746 famílias (Castro, 2004, apud Bittencourt, 2015: 85). Em 2002, grande parte destas famílias já havia sido removida (Collins, 2015: 74). Hoje, elas não passam de 100, sendo 83 famílias moradoras anteriores à reforma (Figueiredo et al., 2017: 12). Estas 83 famílias são parte das 103 (que depois se tornaram 108) que assinaram o já referido TAC. Esse documento garantiu seu direito de uso dos imóveis reformados através do Programa de Habitação de Interesse Social (PHIS).

Figura 5 - Vazios e "carcaças" no CHS, com destaque para a área da 28.

\footnotetext{
${ }^{9}$ Segundo Luana Malheiro, que estudou o consumo de crack no CHS, havia na Rua 28 de setembro três casarões abandonados onde residiam usuários de drogas. Estes casarões se tornaram lugares apropriados para os consumidores experientes, pois lhes permitiam ficar "fora da vista de curiosos e jornalistas" (Malheiro, 2013: 254); já para os "sacizeiros", que não se importavam com a privacidade e se exibiam, as ruas são o próprio local de consumo.
} 


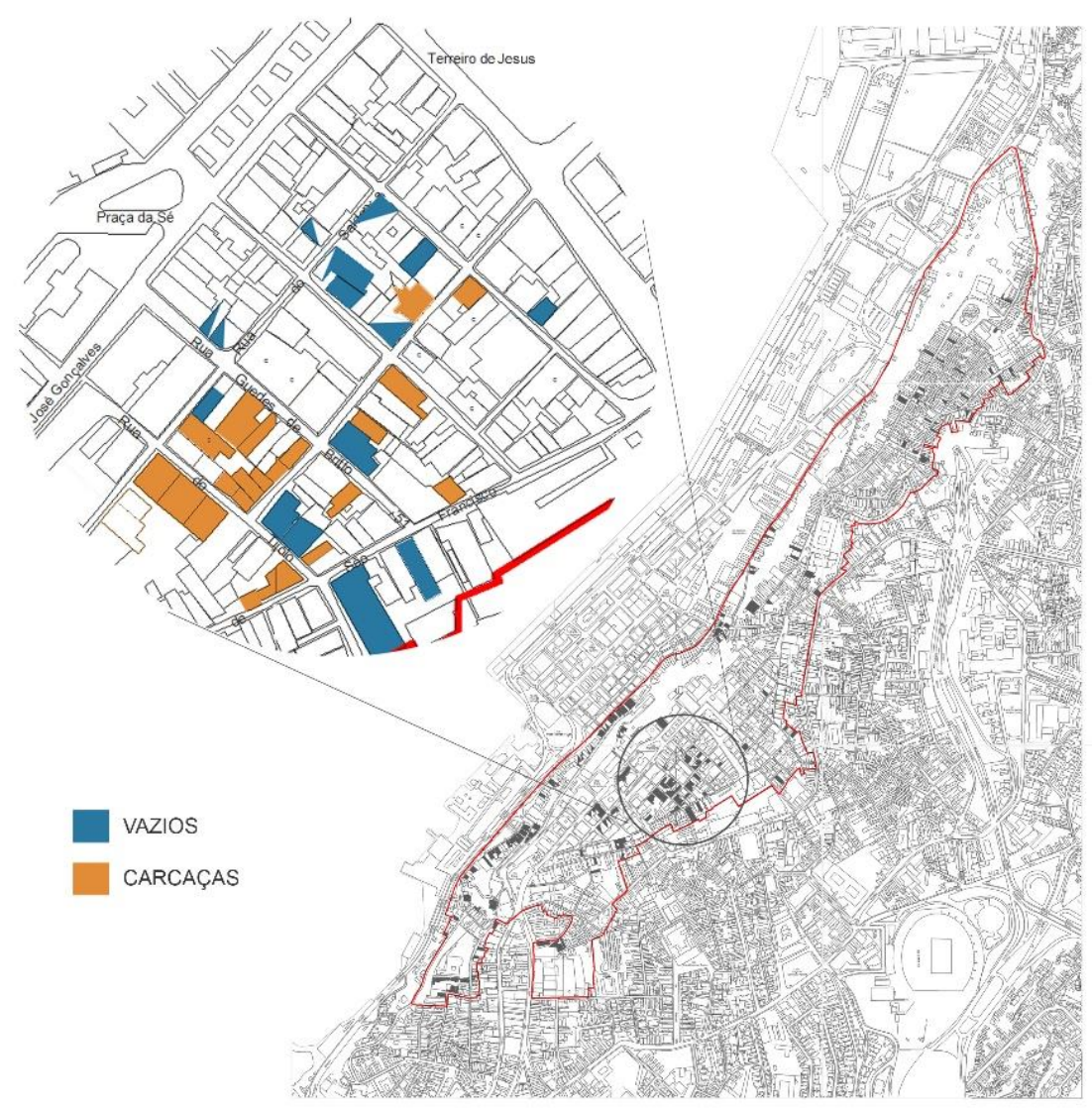

Fonte: ACCS/Panoramas Urbanos, 2019.

Figura 6 - Situação das obras do Projeto da $7^{\text {a }}$ etapa de recuperação do CHS em agosto de 2017.

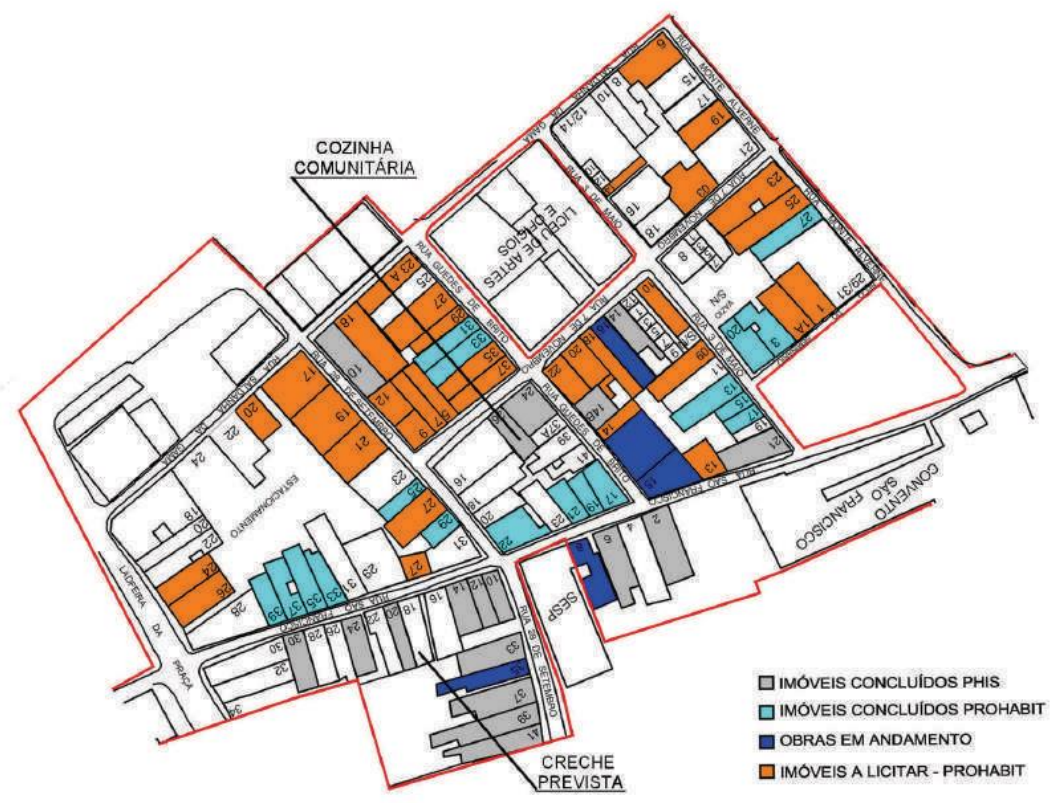

Fonte: Bomfim, Dórea e Santiago, com base em CONDER, 2017, apud Figueiredo et al., 2017: 11.

O esvaziamento populacional do bairro que os números acima provam se explica pelo longo processo de reforma, que deixou, até hoje, vinte anos depois, muitos imóveis 
em escombros, e pelo fracasso do projeto de instalação de novos moradores, evidente no número elevado de imóveis reformados, porém vazios (cf. Figura 5). O Programa de Habitação para Servidores Estaduais (PROHABIT), que previa a instalação de 234 unidades familiares de funcionários públicos, parece não ter sido suficientemente atrativo para povoar a área. Mesmo os que financiaram a compra de imóveis fizeram-no para alugá-los. A presidente da AMACH, Jecilda Mello, calcula em apenas 10\% o número dos moradores novos, ou seja, 8 famílias novas ${ }^{10}$. Ao todo, pois, morariam apenas 91 famílias no que fora o movimentado bairro da 28 . O fato dos moradores antigos serem majoritários permite a Sandra Santos, liderança da AMACH, afirmar: "Ainda estamos por cima da carne seca, mas não vamos ficar porque tem muito mais imóveis destinados aos servidores públicos do que para nós" (cf. Figura 6). Com efeito, o projeto da $7^{\mathrm{a}}$ etapa previa 234 apartamentos para servidores estaduais e apenas 103 para habitação de interesse social (Figueiredo et al., 2017: 12).

\section{Memórias do bairro}

Figura 7 - Sandra, na atual Rua 28 de Setembro, rememorando o passado.

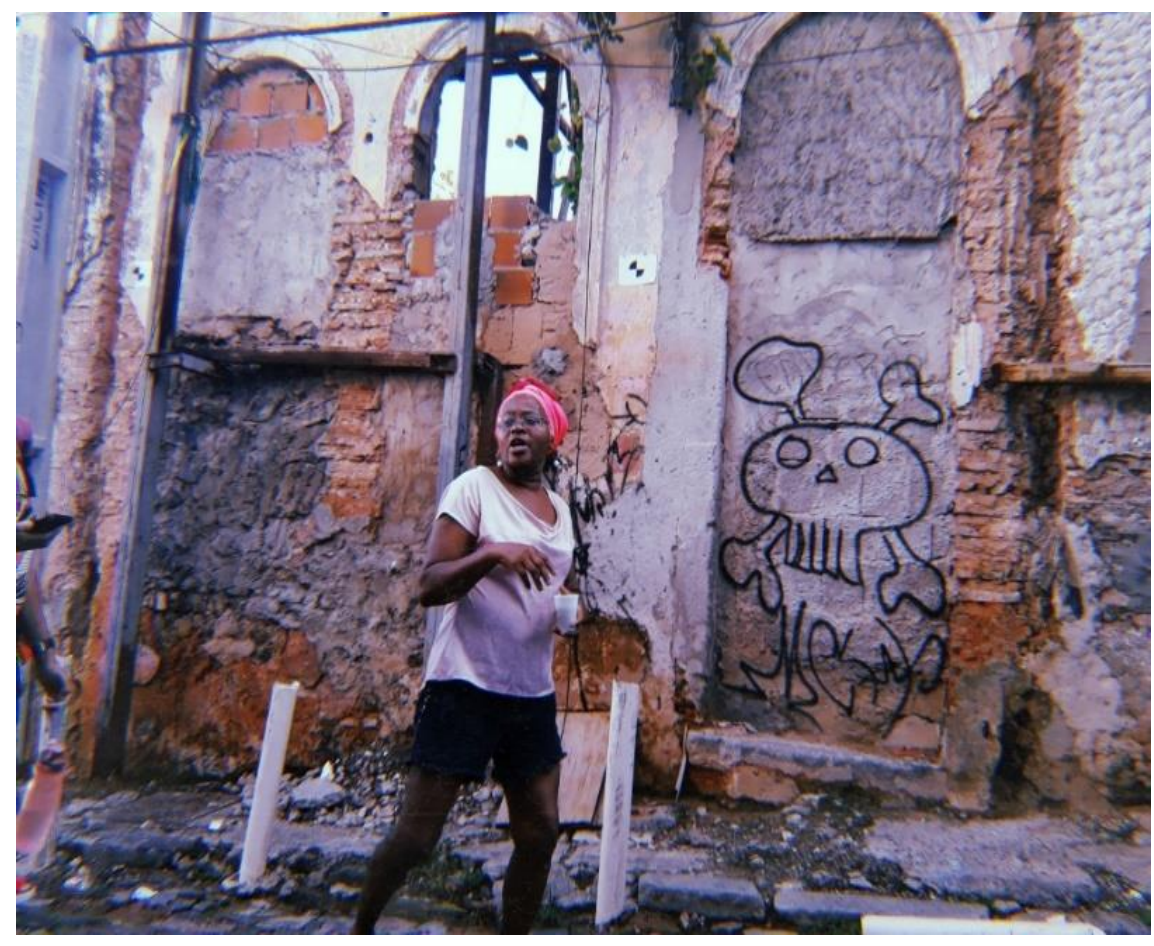

Fonte: ACCS/Panoramas Urbanos, 2019.

\footnotetext{
${ }^{10}$ Numa roda de conversa, Jecilda Mello afirmou que os moradores novos eram muito poucos. Solicitei que calculasse uma porcentagem e, após pensar um pouco, disse que não deviam passar de $10 \%$ do total de moradores antigos.
} 
Para Sandra, Jecilda, Anastácia, Helena, Rita, Edna, Daniel, Eugênia, Tânia e Cícero, a 28 antes da reforma era um bairro bom, ótimo de se habitar. Era um "verdadeiro bairro", daí a repetição da palavra na seguinte frase de Anastácia: "Daqui até a 28 era um bairro, era um bairro, era delicioso, Ave Maria!".

Das narrativas das nossas interlocutoras extraímos que um bairro existe quando há vida em suas ruas. Da mesma forma que a vida dos organismos depende da circulação entre suas partes, os bairros, para os habitantes da 28, dependem da circulação de pessoas para permanecerem vivos. Nos seguintes trechos fica evidente a associação entre bairro vivo e gente indo e vindo: "As ruas tinham vida..." (Helena); "Isso aqui era muito frequentado. O comércio atraía gente de toda a cidade (Sandra); "Aquela época era boa, era vivo, dava gosto de andar" (Rita); "Aqui era muito bom, aqui era muita gente" (Edna); "As pessoas andavam na noite, tarde, de madrugada” (Edna).

Há aqui uma concepção, podemos dizer, biologizante ou organicista do bairro. Ele é considerado um organismo vivo, que requer se nutrir, formado de partes ou órgãos que precisam interagir e pelos quais os nutrientes devem circular. Nesta concepção, o alimento do bairro é o comércio e seu dinamismo é evidenciado pelo número de pessoas em suas ruas.

Embora num contexto muito diferente - Nova York nos anos 1960 -, Jane Jacobs, em Vida e morte das grandes cidades (1973), concebia os bairros de uma forma muito parecida. Para esta famosa ativista, uma cidade viva era feita de bairros vivos, e estes, de ruas vivas. A vitalidade delas dependia de seu caráter público, isto é, de sua frequentação por parte de vizinhos e não-vizinhos. Na visão de Jacobs, os bairros deviam ser espaços abertos, públicos, e não comunidades, sendo a garantia de seu caráter público o comércio verificado em suas ruas. Ela afirmava que lojas, bares, restaurantes, hotéis, oficinas, escolas etc. eram fundamentais para a vida do bairro, pois promoviam relações entre as pessoas, frequentações, diálogos, negociações, favores, olhares. Contudo, os projetistas e urbanistas de ontem e hoje pensavam e pensam o contrário: tudo é feito para diminuir o uso da rua, para impedir que estranhos circulem em ruas cada vez mais privatizadas. $\mathrm{O}$ resultado é o fim dos bairros e, com ele, a morte das cidades.

Nossas interlocutoras concordariam plenamente com Jane Jacobs, pois suas falas apontam para o mesmo entendimento de bairro como um espaço público, um espaço aberto à frequentação indiscriminada: "a 28 tinha muita gente", "gente de toda a cidade"! Nossas 
interlocutoras mencionam em diversas ocasiões como a 28 era frequentada por pessoas de outros lugares, especialmente em eventos importantes como o Carnaval ou o Caruru de Dona Alzira: “Tinha o bloco Tamoios, o bloco de samba Os Nativos que saía no São João, o caruru de Dona Alzira, de Cosme e Damião e de Santa Bárbara, o caruru de Dona Salvina (Sandra)"; "Os blocos afro Apache, Comanche e Muzenza desfilavam pelas ruas daqui" (Eugênia); "Na rua tinha torneio [de baralho]" (Daniel):

\begin{abstract}
Menina, essa 28 de Setembro era um lugar maravilhoso! Como minha mãe dizia: "Se botar cocô aqui enrolado vai vender". E era! Porque todos os bares vendiam almoço, café e janta. Minha mãe comprava por semana - era por semana, gente! - 200 engradados de cerveja! Ela pegava a carreta fechada (...). Vendia-se muito, aqui era maravilhoso! A minha mãe todo ano, no dia 28 de Setembro, ela bancava sozinha com o marido dela a Lavagem da 28 de Setembro (...). Minha mãe pagava as baianas, minha mãe dava comida, minha mãe dava bebida, minha mãe trazia carro pipa, minha mãe trazia carro de som, trazia o diabo todo. Era um caruru de se lascar! De 12 mil, 15 mil quiabos. Teve um dia que eu fiquei surpresa, abestalhada, né? Depois que eu me casei, saí daqui, fui morar num bairro (...). Ai eu estava vindo para o caruru de minha mãe, peguei o ônibus lá no Beiru, Tancredo Neves, e aí um rapaz entrou, estava sentado na janela, aí alguém chamou ele: "Tô indo pro Centro, vou pro caruru lá do 35!". Aí no outro dia eu estava em algum lugar, alguém falando de bingo, ai o rapaz falou assim: "Poxa, rapaz... Só cantou Alzira lá no bingo! [Alzira que morava no 35] A minha mãe ficou tão famosa que, no bingo, quando cantava pedra 35, o pessoal dizia aqui "deu Alzira!". (Sandra).
\end{abstract}

O caráter público do bairro fica evidente em outro dado trazido por Sandra: “ $A 28$ de Setembro era chamada de mão inglesa porque subia e descia ônibus. (...) Depois de algum tempo, os ônibus pararam de descer, só subiam e desciam a Ladeira da Praça”. Depois, acrescentamos, sumiram. Para quem anda pela área hoje custa imaginar que linhas de ônibus circulassem em mão dupla por essa rua estreita, custa acreditar que essas ruas tão esvaziadas fossem um "point" dos blocos de Carnaval e que suas tradições fossem conhecidas em áreas longínquas da cidade.

A vitalidade do bairro, derivada do variado e intenso comércio que existia em suas ruas, é mostrada na Figura 8. Trata-se do mapa das atividades que existiam na 28, construído a partir da sobreposição dos 10 mapas individuais que as subequipes da ACCS preencheram com cada interlocutora. As manchas em azul correspondem aos locais onde havia "comércios": armazéns, mercearias, açougues, padarias, lojas de materiais e produtos de eletrônica, de instrumentos musicais, lotéricas, lavanderias, barbearias, salões de beleza, alfaiatarias, costureiras, restaurantes etc. $\mathrm{O}$ azul que representa este comércio variado é a cor predominante no mapa: as interlocutoras lembram de aproximadamente 50 estabelecimentos comerciais espalhados pelas 8 ruas. Este número não incluía um tipo de comércio específico, os bares, que, pela sua quantidade e especificidade, optamos por 
representar em vermelho. Foram nomeados mais de 26 bares na 28, com uma concentração maior na área da Rua 28 de Setembro. Por outro lado, o comércio incluía também hotéis, destacados em cinza: eram 4 no interior do bairro. Por fim, não podemos deixar de destacar um comércio particular, o comércio dos corpos: eram 8 os cabarés ou "bregas" que existiam no bairro.

Figura 8 - A vitalidade da 28. 


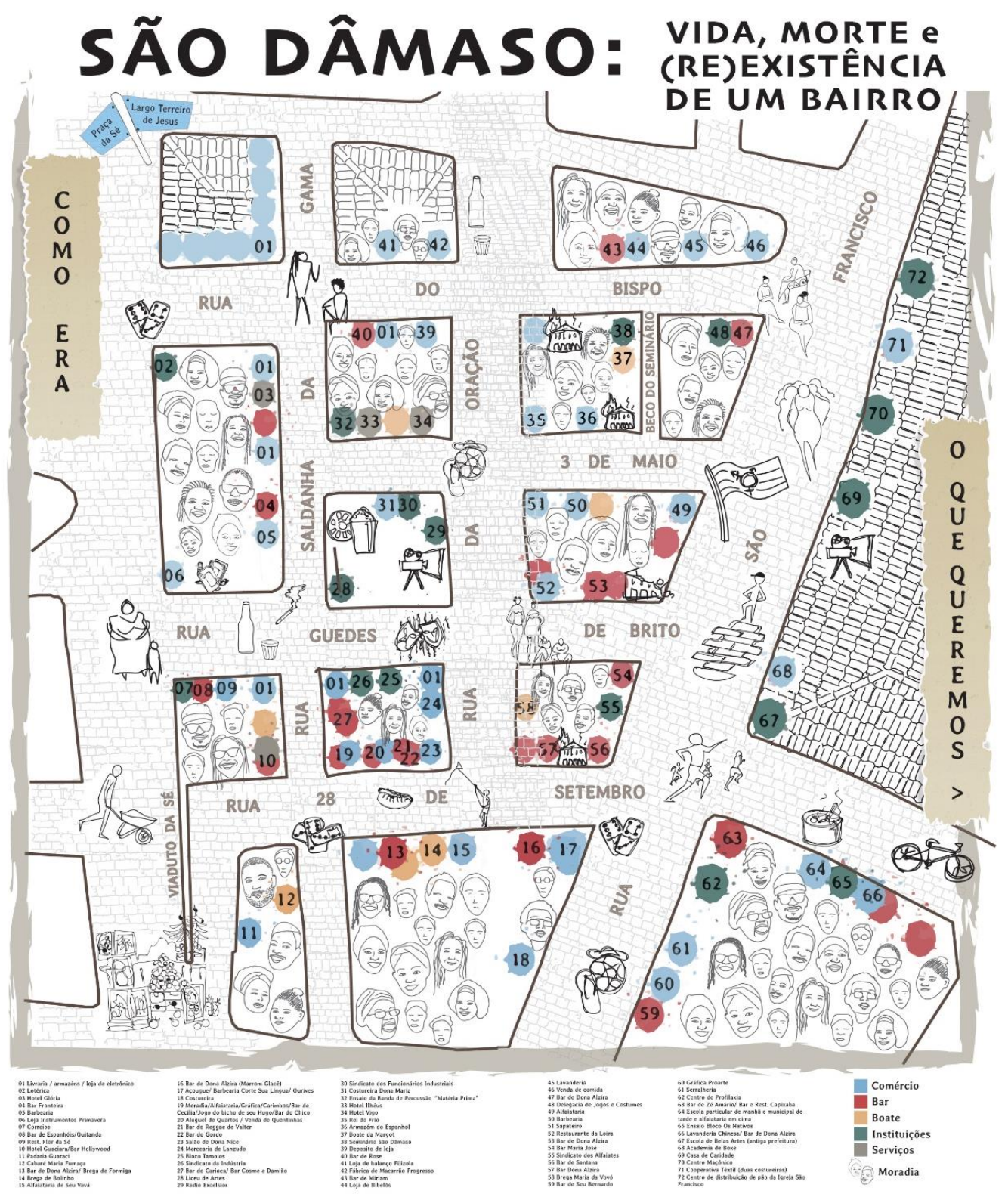

Fonte: ACCS/Panoramas Urbanos.

Fica demonstrada a vitalidade do bairro: um comércio variado, de todos os tipos, em grande quantidade. Eram mais de 100 estabelecimentos, ao todo, em 8 ruas, que asseguravam o vai-e-vem de pessoas conhecidas e desconhecidas.

O caráter público era reforçado pela presença no bairro de instituições públicas que atraíam muitos frequentadores externos assíduos. Contabilizamos 16 instituições, dentre as quais destacamos os Correios, a Escola de Belas Artes, alguns sindicatos, o Liceu de Artes e Ofícios, uma rádio, uma delegacia e um centro maçônico.

A pesquisa histórica de Samuel Gordenstein (2014), embora limitada à Rua 28 de Setembro, nos permite afirmar que os usos mistos desta área podiam ser encontrados, pelo menos, desde meados do século XIX. A minuciosa pesquisa realizada pelo arqueólogo 
nesta rua, então chamada de Rua do Tijolo, encontrou os seguintes usos dos imóveis no período entre 1850 e 1870 :

Figura 9 - Usos dos imóveis da Rua do Tijolo entre 1850 e 1870.

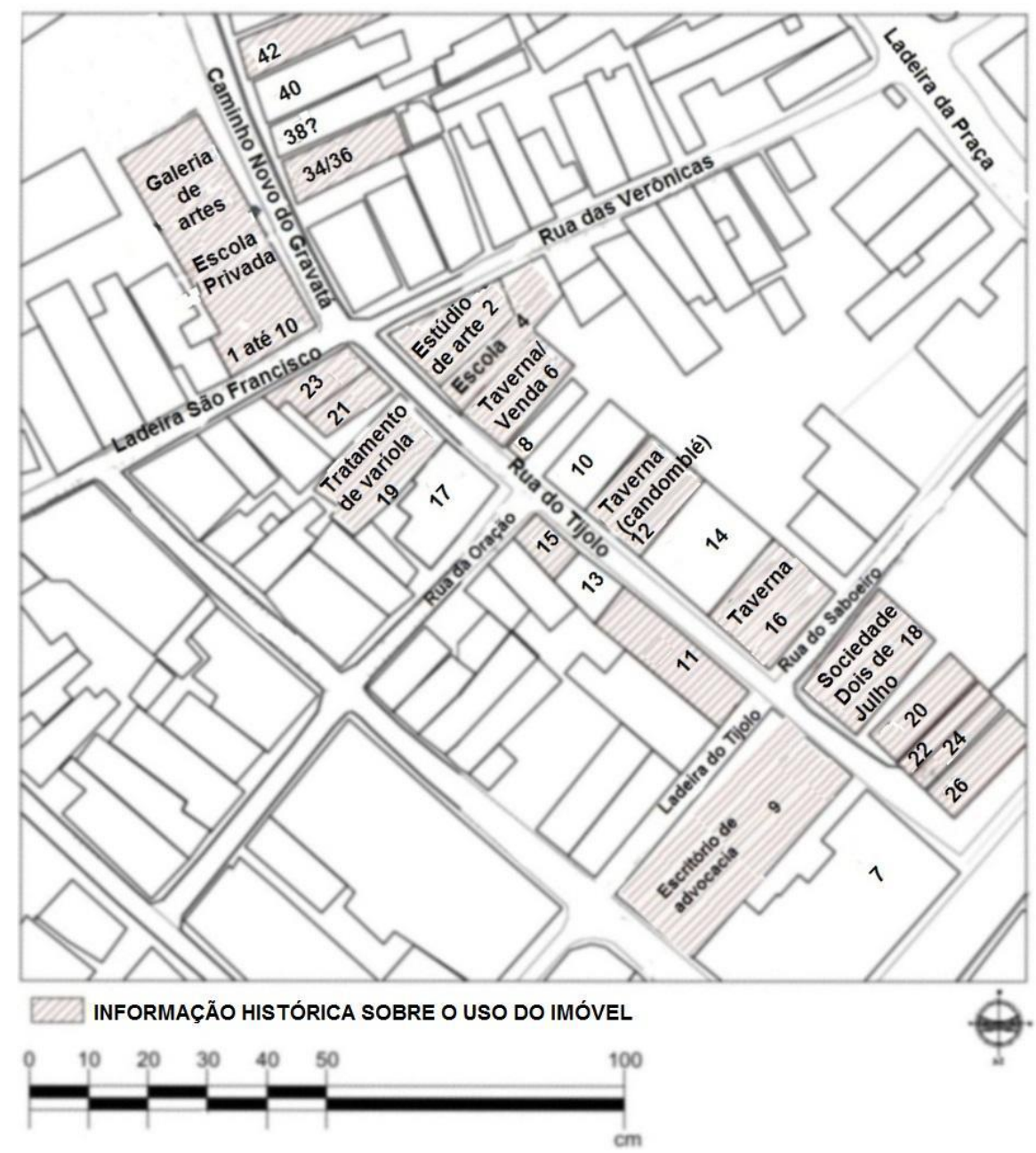

Fonte: Gordenstein, 2014: 54.

O texto de Gordenstein prova que, ao menos desde o século XIX, a 28 era uma área na qual os usos comerciais e institucionais se misturavam aos usos residenciais. Dentre os usos comerciais, chama a atenção o número de tavernas/vendas que havia - locais onde se podia comer, beber, jogar e reunir-se; no período entre 1855 e 1870, eram ao menos 11 (Gordenstein, 2014: 67). Também era grande o número de sedes institucionais ligadas às artes, educação e profissões liberais. Os setores sociais que frequentavam tavernas e sedes deviam ser diversos, outorgando um caráter "eclético" à rua. Nos 27 imóveis dela, predominavam os moradores inquilinos (somente em quatro casos o proprietário era também morador), que se dividiam em, de um lado, os funcionários públicos 
(representando 38,46\% da amostra da rua), profissionais liberais e comerciantes e, do outro, as pessoas "menos abastadas", dentre as quais profissionais de ofícios $(10,77 \%)$, estudantes e africanos:

\begin{abstract}
Era uma rua eclética, de contrastes, moradia dos heróis do combate às epidemias e foco das tavernas. A Rua do Tijolo contava com a forte presença da classe média (classe "B" na tabela acima), composta principalmente por comerciantes, profissionais liberais e servidores públicos, com destaque para o grande número de médicos e, principalmente, taverneiros. Sozinha, essa classe "B" representava $55 \%$ daqueles listados nos almanaques consultados. Na classe "C", de salários menores, salta aos olhos o grande número de funcionários públicos, que são 15 , atuando em posições consideradas subalternas. A Rua do Tijolo, muito próxima das instâncias administrativas e políticas do Estado (bastava subir a rua), mostrou-se irresistível como local de moradia a esta categoria de trabalhador. Aliás, essa proximidade geográfica provavelmente era importante para os muitos médicos da rua que trabalhavam também como professores da Faculdade de Medicina, que ficava a uma curta caminhada a pé, no Terreiro de Jesus. (Gordenstein, 2014: 76)
\end{abstract}

A população que morava na 28 se tornou, um século depois, muito diferente. Como acontecera com todo o CHS, a área foi se pauperizando progressivamente ao longo do século XX. No entanto, a saída dos mais abastados começara antes, na segunda metade do século XIX. No caso da Rua 28 de Setembro, a mudança dos funcionários públicos para outras áreas da cidade estava diretamente vinculada à importância comercial popular crescente da Rua da Vala (atual Baixa dos Sapateiros), evidente em seus cantos de ganhadores e seus muitos artesãos (sapateiros, ferreiros etc.). Mas, também, estava relacionada às linhas de bonde que lhes permitiriam morar longe de seus locais de trabalho. Nos anos 1970, sua população devia muito se parecer à descrição do Maciel feita por Gey Espinheira (1971) em finais da década de 1960: uma população pobre, com mão de obra não qualificada e subutilizada, vivendo em ocupações esporádicas e recebendo baixíssimas remunerações.

Afirmar que o bairro era público porque aberto à cidade ou à frequentação de estranhos não é incompatível com a afirmação dos laços que uniam seus habitantes. Com efeito, o movimento das ruas advinha tanto destes quanto dos estranhos que partilhavam o espaço das ruas e dos estabelecimentos do bairro.

Os laços entre vizinhos que nossas interlocutoras aludiam frequentemente em seus depoimentos procediam, em primeiro lugar, do fato de todo mundo se conhecer, por estarem ou se encontrarem nas ruas: "As festas, as brincadeiras, as amizades, tudo era aqui, era todo mundo conhecido" (Anastácia). Essas pessoas compunham "uma grande família", o que significa dizer que havia confiança, ou, em termos negativos, que não havia 
vergonha, etiquetas ou protocolos de distanciamento. A mãe de Sandra, por exemplo, cozinhava no meio da rua, tal qual, ela mesma compara, se fazia no Maciel (cf. Figura 10):

No Maciel tinha uma coisa boa, era tudo esburacado, tudo acabado, e quem não tinha botijão de gás nem fogão já pegava uns gravetos, fazia uma fogueira na sua porta do prédio e cozinhava suas panelas ali, o pessoal cozinhava no meio da rua. Lá embaixo, na 28, minha mãe, quando fazia caruru, com muitas panelas grandes, ela arranjava uns gravetos por aí e colocava as panelas tudo do lado de fora para cozinhar, todo mundo via cozinhando tudo. (Sandra)

Figura 10 - No Maciel, como na 28, tudo se fazia no meio da rua.

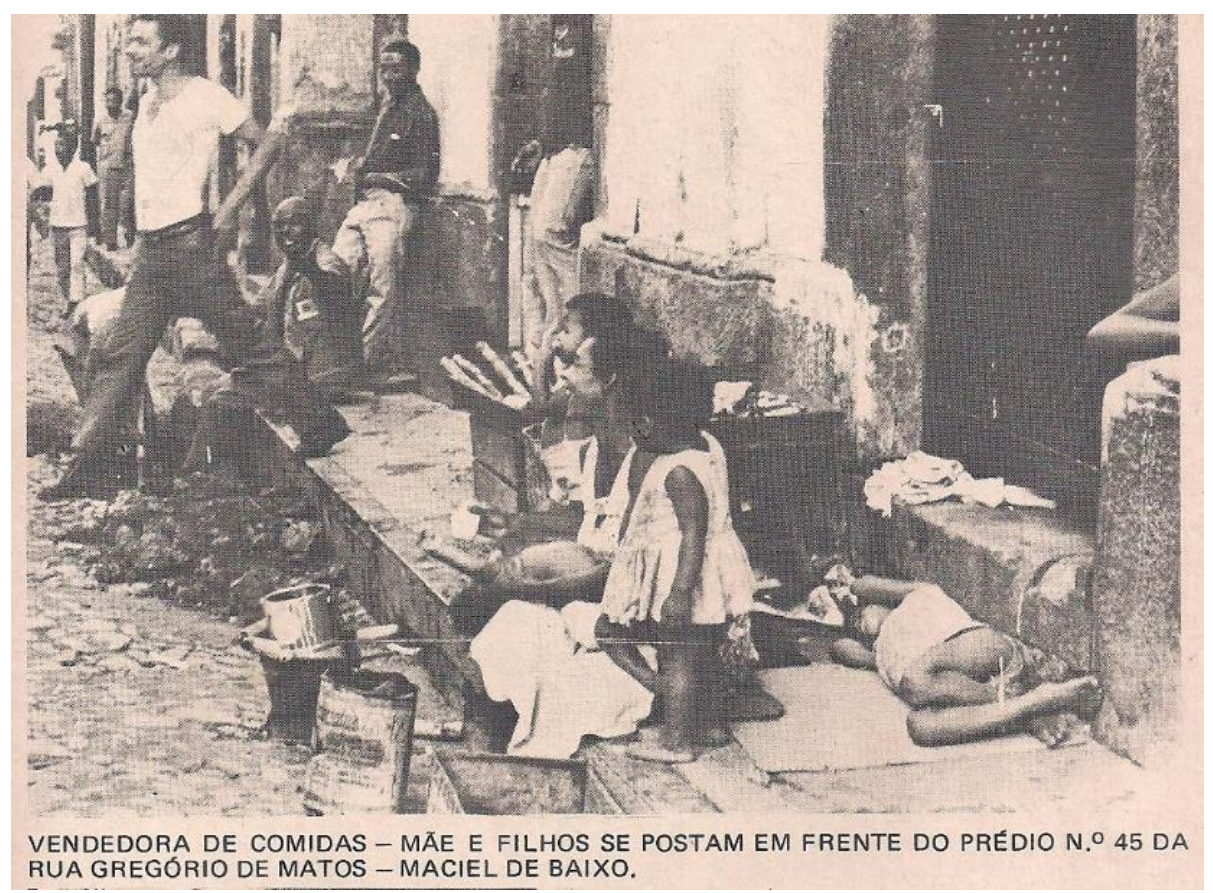

Fonte: Espinheira, 1971: 39.

Além de se conhecerem, os vizinhos da 28 estabeleciam relações entre si. Dentre elas, na memória das nossas interlocutoras, primavam as relações de ajuda mútua e consideração, que tornavam os habitantes da 28 vizinhos de porta ou vizinhos de rua, parentes ou não, locadores ou (sub)locatários, uma "grande família". Dona Alzira, mãe de Sandra, sublocava muitos cômodos da 28 , tinha muitos bares em muitas casas. Poderia se pensar que fez fortuna. Contudo, Eugênia, sua filha adotiva, afirma: "Infelizmente, não. Teve um momento que as pessoas pararam de pagar mainha, aí ela não tinha mais dinheiro para reformar os prédios". Não morreu rica porque entre ela e suas inquilinas havia consideração: 
Quando uma inquilina da minha mãe engravidou, ela não tinha mais como se prostituir, e ela era prostituta. Então minha mãe dizia: "A partir de agora você não paga mais quarto, até você ter o seu filho e passar o seu resguardo”. Minha mãe não cobrava o quarto, dava a comida dela e aí ela ajudava na casa, ajudava na cozinha, a fazer uma comida, a catar o feijão, a passar uma vassoura na casa, ajudava em alguma coisa. Que minha mãe dizia assim: "Olhe, aqui é a casa do bom homem, quem não trabalha não come”. Então, todo mundo tinha que trabalhar, mesmo que o seu trabalho fosse secar os pratos, os talheres, mas você pagando o seu estar (...). Então, a gente aqui sempre se ajudou, sempre nos ajudamos mutuamente aqui. (Sandra).

A consideração entre os habitantes significava uma preocupação com o vizinho e uma prática de ajuda, dentro das possibilidades de cada um:

\begin{abstract}
Nós sempre nos ajudamos aqui. Eu tive um problema com um filho meu e infelizmente esse problema terminou que levou meu filho, mas, assim, precisávamos fazer uma tomografia computadorizada que naquela época era 40 poucos mil, era caríssima, e minha mãe só tinha 17 mil no banco, era tudo que minha mãe tinha. Mas os vizinhos se mobilizaram e no dia seguinte nós fizemos. Minha mãe conseguiu 23 mil que nos deram. Um deu 10, o outro deu 5, o outro 5 (...). E fizemos! Hoje (...), meu Deus, se eu tivesse um vizinho para me dar 50 conto (...). Que hoje a situação está terrível, mas a gente sempre se ajudou. (Sandra) .
\end{abstract}

Conforme lemos nas últimas linhas, não há mais esta consideração, essa ajuda mútua, porque não há mais gente nas ruas com as quais estabelecer e tecer relações; não há mais muitos e muitas vizinhas, vivendo uns ao lado dos outros. Os poucos remanescentes do bairro da 28 estão hoje concentrados em apenas 2 quarteirões (cf. Figura 6).

A consideração é um valor que media relações entre pessoas. Na prática, consiste em se dar mutuamente atenção, fazer trocas materiais, emprestar objetos e dinheiro, colaborar profissionalmente etc. Segundo João de Pina-Cabral e Vanda Silva (2013), a consideração é o elemento central encontrado nas relações no interior das casas, parentelas e vicinalidades na Bahia:

(...) A consideração é o tecido do qual é feito a casa, tanto quanto a parentela de cada pessoa, tanto quanto a vicinalidade: a "casa" é a instância coletiva mais proeminente da sociedade local; a parentela (referida tantas vezes pela frase "a minha família', expressão muito plástica) é a rede de relações que existe em torno de cada pessoa e ultrapassa necessariamente a pertença à casa; a vicinalidade é o grupo de casas aparentadas localmente e que constituem a família no sentido operacional. (Pina-Cabral; Silva, 2013: 40).

Se a casa é o espaço de acolhimento, onde as pessoas se sentem acolhidas, onde recebem consideração, não é incorreto dizer que, nas memórias das mulheres que 
habitaram a 28, as funções da casa eram exercidas pelo bairro ou o bairro era uma grande casa.

Entretanto, é preciso frisar que, assim como a casa não elimina os desentendimentos em seu interior, o bairro não é feito apenas de consideração e ajuda mútua. Um bairro se faz, também, de brigas, porque elas são parte do convívio, da interação, da negociação cotidiana que movimentava as ruas. As brigas são parte da vida e não algo fora dela. São parte da "grande família". É esse o entendimento de Anastácia:

A 28 de Setembro era considerada a rua mais perigosa do Centro Histórico. Mas não tinha muita violência no local. Tinha era brigas de família e entre casais. Era isso que tinha, como em qualquer outro bairro (...). A gente era até muito protegida por todos, porque a gente se conhecia e todo mundo se gostava, então não tinha problema.

Se as brigas são concebidas como interação e esta como a força vital de um bairro, as brigas passam a ser louvadas, conforme fica evidente nesta declaração de Sandra:

Era um brega da porra. Era uma guerra, toda hora era uma briga (...). Os meninos brigavam, mas nós éramos tão felizes (...). Dia de domingo a gente sentava nesses passeios todos aí, cada hora saía um prato da casa de um, comprávamos uns garrafões de 5 litros de vinho, as Coca-Colas de 2 litros, eita diacho! Os moleques saíam tudo para jogar bola e tome-lhe quebrar vidro dos outros (...). Já tomei uma bolada na cabeça!

Guerra e felicidade, amor e ódio, família e briga, não são, nesta lembrança de bairro, antônimos:

É como uma grande família. Nós éramos uma grande família. Tem horas que nós nos dávamos bem, quando um respeita você se dá bem, quando não, você não se dá bem (...). A gente se amava e se odiava. Eu morei no quarto numa época, eu já tinha netinho, morava uma menina em cima de mim e ela tinha uma filha. Ela saía para "batalhar", ela era prostituta, e a menina dela, Amanda, ficava dormindo. Eu nunca briguei com ela, não tinha como brigar. Não era laje, nossas divisões eram de madeira. Amanda abria a torneirinha [Jecilda completa: "Oh Jesus (...). E a água ia toda para sua casa”.]. Como é que eu ia brigar? Eu sabia que ela estava trabalhando e era uma criança que fazia isso, não tinha como brigar. Pessoas jogarem baldes de água, bacias de água, sem prestar o mínimo de atenção, aí você vê que é irresponsabilidade, e quem morava embaixo sempre sofria muito isso. (Sandra).

A convivência via-se dificultada pelas condições dos imóveis, mas resultava igualmente do que nossas interlocutoras chamam da "cultura local", formada, entre outros elementos, do costume de jogar as coisas pela janela. Hoje, elas lembram esses hábitos sem muita reprovação: 


\begin{abstract}
Ali era só lixo (...). Nos anos 70, quando eu cheguei aqui, você tinha que ver o que era 31 de dezembro, as pessoas jogavam tudo pela janela, era cama velha, colchão velho, sofá velho (...). Descia tudo pela janela, o povo fazia questão de jogar tudo, as ruas ficavam intransitáveis, era a cultura daqui, jogar tudo pela janela. Era uma loucura! (Sandra)

Tinha uma mulher que, quando brigava com o marido, coitado de quem passasse na rua, era tudo pela janela do prédio (...). Era a cultura aqui, se fosse velha jogava para o canto e se fosse boa alguém levava. (Jecilda)

A minha mãe, coitada, (...) ela vinha subindo a rua e recebeu uma panela de água com gordura fervendo. $O$ vizinho ferveu a panela de carne, charque, $e$ minha mãe recebeu tudo pelas costas. Saiu o couro das costas de minha mãe todo! (...). (Sandra).
\end{abstract}

A 28 tinha seus modos próprios de resolver problemas, dentre os quais nossas interlocutoras não negam a presença da violência física:

\begin{abstract}
Eu vi muitas mulheres apanhando de homem, não só de gigolô, não, a cultura aqui era de espancar a mulher (...). Quando eu me casei, meu marido, ele queria fazer igual. Acabou um dia nós dois no HGE [Hospital Geral do Estado], eu com um tiro e ele todo furado de garrafa. Nunca mais ele quis me bater. Começaram a surgir mulheres assim: "Já que eu vou morrer, vou matar também o desgraçado” (...). As mulheres foram acordando para isso (...). A minha mãe tomou 14 facadas do marido. Eu só ouvi um choro, mainha estava lá, arriada. Ele era muito ciumento.
\end{abstract}

Daniel, por sua vez, fala da violência entre as mulheres. Contou-nos que era uma prática frequente entre as mulheres se cortarem umas às outras com canivetes de navalhas:

Se soubesse que uma estava com o marido da outra aí pegava e [imita o som do corte] (...). Você vê com a marca do rosto, já ficou gravado (...). Nesse tempo não dava facada, não, se cortava era com Gilette. (...) Matar assim não era muito dificil (...). Deixava era uma marca para quem ver saber que pegava homem dos outros. Aquelas coisas, né? Naquele tempo de louco, até hoje, né?

Essa violência, hoje, parece ser aceita pelas interlocutoras. A razão dessa aceitação não deve ser buscada na tolerância ou relativismo cultural delas, mas no antropocentrismo de suas memórias. Na visão delas, as condutas violentas não tornam necessariamente seus atores pessoas violentas. As ações, assim como as formas de sobrevivência das pessoas, não se confundem com o valor delas. $\mathrm{Na}$ frase que segue, Eugênia coloca uma série de atividades que permitiam a sobrevivência dos moradores da 28. Repare-se que a prostituição é mais uma na lista: "As pessoas tiravam seu sustento sem sair do bairro: lavavam roupa, cuidavam de crianças, colocavam suas guias na porta de casa, vendiam cachorro quente, se prostituíam”. 
Mesmo quando se tratava de atividades consideradas por uma grande parcela da população como ilegais ou imorais, como a venda ou tráfico de drogas, o que se ressalta é que as pessoas que as faziam ou desempenhavam podiam ser "m-a-r-a-v-i-l-h-o-s-a-s":

\begin{abstract}
Lá em cima, no Maciel, na 28 de Setembro, lá na minha casa, no número 35, tinha aqueles que vendiam. Cá em cima na Rua São Francisco, no número 6, Dona Noêmia vendia também. Noêmia era maravilhosa, maravilhosa! Dona Noêmia começou a vender crack, aí chegou um dia, era aqui na São Francisco, ela pegou um pedaço de cera de carnaúba, cortou e fumou (...), aí os drogados começaram a comprar. Quando ela vendeu uns 30, 40 reais, ela partiu: "Vou embora dar comida a meus filhos antes que alguém me mate". Ela vendeu cera de carnaúba. Ela disse: "Meus filhos estavam com fome". Ela vendia droga paraguaia e, como ela vendia andando pela rua, ninguém mais ia ver a cara dela. Ela queria a comida dos filhos dela. Ela morava aqui, mas descia para vender cá embaixo, na Baixa dos Sapateiros. (Sandra)
\end{abstract}

Os modos de conviver da vizinhança da 28 - a "cultura do Centro Histórico" incluíam solidariedade, jogo, consideração, assim como violência física e jogar coisas pela janela; e, também, a proximidade dos diferentes, tais como costureiras, prostitutas e "mães":

\begin{abstract}
Olha, aqui [Rua São Francisco] funcionava um bar. Sim, em cima era moradia, embaixo era bar de Val que está com um bar aqui na 28, Val. A particularidade que tinha aqui é que $80 \%$ dos moradores daqui eram travestis (...). A parte de cima do São Francisco tinha costureiras, dois prostíbulos. Eu já não me lembro os nomes. Se eu não me engano, era o Círculo 7, era o prostíbulo. Ainda tem bar e camisaria, a costureira e o prostíbulo não existem mais (....).Então, aqui é a São Francisco, era parte da Igreja, muitas famílias pobres vinham aqui para a frente da igreja para ganhar pão, para ganhar roupa, algum sustento. Enchia muito aqui, muitas mães, muitas senhoras com crianças, mais de fora (...). (Eugênia).
\end{abstract}

O bairro da 28 tinha todo tipo de gente, vivendo umas ao lado das outras, inventando regras para viverem juntas. A diferença não era suprimida, mas aceita. Naturalizada. Neste trecho, quando Sandra nos narra as atividades desenvolvidas na Rua da Oração, chama a atenção o convívio que ela, quando criança, tinha com esse tipo de trabalhadoras:

Aqui era a casa de minha avó. Aqui tinha, primeiro do lado de cá, depois veio para cá, o Rei do Frio, era uma oficina de refrigeração. A partir disso era uma casa de eletrônica, na ponta era eletrônica e, descendo por aqui tudo, era um prostíbulo. Os três prostíbulos aí e cada esquina um hotel. E aí, no intervalo do meio, eram dois ou três prostíbulos. Eu ia lá todo dia, onze horas, onze e meia, levar marmita para as putas comprar. Ô, minha filha, eu só chegava na escola atrasada, porque eu tinha que distribuir a comida de minha mãe na cidade toda. Eu descia o Elevador Lacerda, que ali era cheio de barracas de flores, para 
vender comida para aqueles floricultores todos ali. Descia o Plano Inclinado para vender marmita para todas as pessoas que vendiam ali frutas, essas coisas. Eu chegava na escola uma hora, uma e meia!

Apesar da separação ou distinção que se fazia no interior do bairro entre locais de prostituição e locais de moradia, o estigma marcou o bairro todo como sendo um "brega". "Brega" é o nome dado aos locais onde as prostitutas aguardavam seus clientes em um ambiente caracterizado pela liberdade e permissividade. Enquanto os jornais e a chamada opinião pública faziam críticas morais e higiênicas à prostituição e ao ambiente "degenerado" que ela criava na 28 ou no Maciel, Sandra tinha uma concepção outra:

Eu fiquei viciada em brega, gente. Porque eu nasci aqui praticamente, não nasci, mas vim para cá pequena, então, eu vivia aqui e o brega era muito bom. Quando eu chegava numa cidade (...), viajávamos muito eu e os meus primos, aí eu: "Vamos procurar um brega!" Porque o brega era um lugar alegre, ai a gente ia para o brega beber, comer e dançar. A gente só ia para os bregas da cidade (...). O brega é que era o lugar de você ser feliz, gente!

A 28 era um bairro com vida, um bairro habitado. O que as memórias das nossas interlocutoras nos dizem claramente é que bairro bom não é aquele com tantos metros quadrados de área de lazer, ventilação da moradia, acessibilidade das ruas, material nobre dos imóveis, qualidade das calçadas ou garantia de privacidade. Bairro ruim não é bairro pobre. Para as nossas interlocutoras, bairro bom é bairro com gente interagindo, vizinhos e estranhos, e todo tipo de comércio. Bairro bom é aquele no qual se pode morar e mercar, no qual, como diz Eugênia, “as pessoas tiravam seu sustento sem sair do bairro”.

\section{Memórias antropocentradas do bairro versus discursos de degradação e ruínas}

Como vimos, quando nossas interlocutoras falam do bairro de antigamente, destacam o movimento, o comércio, as atividades e as ruas cheias de gente que estas promoviam. Destacam a presença nas ruas de estranhos e vizinhos, com quem se estabelecia relações de consideração, mas também se brigava; mas nunca se deixava de relacionar com.

Esta visão positiva de rua discrepa da forma como ela costuma ser abordada ou descrita em grande parte da literatura brasileira sobre o tema, escrita desde o ponto de vista daqueles que privilegiam a casa. Para estes, as ruas aparecem como espaços mal afamados, 
desinteressantes e desimportantes ${ }^{11}$. Baseado num conjunto de atitudes de um ente genérico chamado brasileiro, Roberto da Matta consagrou a visão segundo a qual o povo brasileiro valoriza e respeita a casa e desvaloriza e desrespeita a rua:

\begin{abstract}
Jogamos o lixo para fora de nossa calçada, portas e janelas; não obedecemos às regras de trânsito, somos até mesmo capazes de depredar a coisa comum, utilizando aquele célebre e não analisado argumento segundo o qual tudo que fica fora de nossa casa é um "problema do governo!". Na rua, a vergonha da desordem não é mais coisa nossa, mas do Estado" (Da Matta, 1985: 16-17).
\end{abstract}

Este autor considera casa e rua como "províncias éticas" (1985: 12) que promovem atitudes, valorizações, imagens e emoções. Ao domínio da casa corresponderiam as pessoas, enquanto, ao da rua, o desumano, impessoal e anônimo. Enquanto a primeira guardaria relação com os valores da lealdade, simpatia, bondade e hospitalidade, a segunda se referiria à lei, à burocracia e ao formalismo. À segurança e confiança da casa corresponderia o perigo e a luta da rua. O modelo de Roberto da Matta se inspira na obra de Gilberto Freyre (2004), para quem a casa era, também, “um campo do qual irradiam-se modelos de comportamento, comandos, símbolos e, sobretudo, relações sociais. Todo um sistema de vida e de dominação" (Da Matta, 2004: 17).

Quando as abstrações e generalizações são confrontadas a materiais empíricos concretos, a operação metonímica dos postulados que tomam a parte pelo todo fica evidente. As memórias sobre a 28 que recolhemos entre as nossas interlocutoras nos mostram outro ponto de vista, ou outro modelo, de um setor específico dos brasileiros. Para elas, as ruas centrais de seu bairro são "tudo de bom": local de trabalho e diversão, de relações e entretenimento, de contemplação e ação, de sustento e aconchego. A casa sequer é mencionada.

Em bairros centrais compostos de pequenos sobrados unifamiliares parece razoável a distinção entre espaços abertos e espaços fechados. Referindo-se à parte central do bairro do Catumbi, no Rio de Janeiro, na década de 1970, Carlos Nelson dos Santos distinguiu os espaços fechados ou privatizados (casas, oficinas, escolas, bares) dos “espaços abertos" ou

\footnotetext{
${ }^{11}$ Uma das raras exceções é, certamente, o carioca João do Rio. Não há dúvida de sua compreensão outra sobre a rua quando, em inícios do século XX, escreveu "Eu amo a rua". Com efeito, ele amava a rua porque ele amava a cidade, que considerava um espetáculo para se gozar, para se vivenciar com todos os sentidos. Se as ruas eram a própria alma da cidade, elas, por sua vez, tinham sua própria alma, isto é, espírito e história: "Há ruas honestas, há ruas ambíguas, ruas sinistras, ruas nobres, delicadas, trágicas, depravadas, puras, infames, ruas sem história, ruas tão velhas que bastam para contar a evolução de uma cidade inteira, ruas guerreiras, revoltosas, medrosas, spleenéticas, snobs, ruas aristocráticas, ruas amorosas, ruas covardes, que ficam sem pingo de sangue...” (Do Rio, 2008: 34). Sobre este autor, ver Montoya Uriarte, 2011.
} 
de uso coletivo (ruas, largos, praças, praias), espaços efetivamente públicos ou vistos como tais (Santos et al., 1981: 13). O que determinava cada um desses espaços era suas atividades e usos. Assim, podia-se "abrir" espaços a princípio fechados e "fechar" espaços a princípio abertos. Nelson dos Santos confere, desta forma, o peso absoluto às atividades e não a uma suposta essência pré-definida dos espaços: "Os significados que um determinado suporte material (esquina, calçada, quintal, rua etc.) pode assumir resultam da sua conjugação com uma atividade e mudam de acordo com ela" (idem: 48).

O Catumbi de Nelson dos Santos foi definido como um sistema ou conjunto articulado de espaços - casa, rua, quintal, calçada, meio da rua, janelas, portas e balcões com um código de uso produzido e reproduzido pelos seus habitantes. Em contraste com a observação-participante que permitiu captar este sistema, nós dispomos apenas de memórias e, nelas, não há nenhuma referência às casas, sua importância ou características. Um antropólogo que fez trabalho de campo na área da 28 antes de sua reforma, John Collins, percebeu esta insignificância da casa entre os moradores:

\begin{abstract}
Nos primeiros anos do novo milênio, os moradores de Pelourinho quase nunca percebiam suas casas como espaços sentimentais ou lugares convidativos. Eles afirmavam de forma esmagadora que os imóveis eram simples recursos que os protegiam e ofereciam um lugar para "deitar a cabeça". (Collins, 2015: 98, tradução nossa)
\end{abstract}

Como entender este silêncio em relação à casa? Parece-me que ele pode ser revelador, de um lado, de uma distinção importante para as nossas interlocutoras entre casa e quarto, e, de outro, de um antropocentrismo que se opõe ao materialismo de quem só consegue ver no CHS imóveis degradados.

Se considerarmos as casas como estruturas físicas independentes para alojar unidades familiares particulares, podemos dizer que, na 28, praticamente, não havia casas. $\mathrm{Na}$ época lembrada pelas nossas interlocutoras a maior parte dos imóveis dessa área se compunha de casarões de dois ou três pavimentos, subdivididos em quartos, formando o que se conhece como cortiços ou casas-de-cômodos. Casas mesmo havia poucas ${ }^{12}$. Assim, as nossas interlocutoras podem não falar de casas por distinguir casa de casa-de-cômodos. A casa seria um espaço independente e a casa-de-cômodos ou cortiço seria um espaço de habitação coletiva. Em contraste com as memórias, hoje, elas se referem a suas "casas",

\footnotetext{
12 Não temos o número exato para a 28, mas sabemos que, nas 8 ruas que compunham o vizinho Maciel, havia 223 imóveis, dos quais 132 eram casas-de-cômodos e apenas 27 casas ou unidades residenciais de grupos familiares. O restante eram imóveis comerciais, em ruínas, em conserto ou fechados (Espinheira, 1971: 15). A 28 não devia ser diferente.
} 
pois têm espaços privados com cozinha, banheiro, sala e ao menos um quarto. O que elas tinham antes eram diminutos espaços que serviam para dormir. Neste sentido, podemos retomar a frase que escrevemos no início deste texto: elas ganharam a possibilidade de habitar casas, mas perderam seu bairro.

A seguir (cf. Figura 11) reproduzimos uma planta que aparece no livro Comunidade do Maciel, de Gey Espinheira (1971), e que ilustra como o espaço físico de uma casa (ou sobrado, pois de dois pavimentos, com 2 dormitórios, 2 salas, 1 cozinha e 1 loja) podia dar lugar a 27 quartos, onde dormiam 27 famílias.

Figura 11 - Quartos em um sobrado do Maciel na década de 1970.

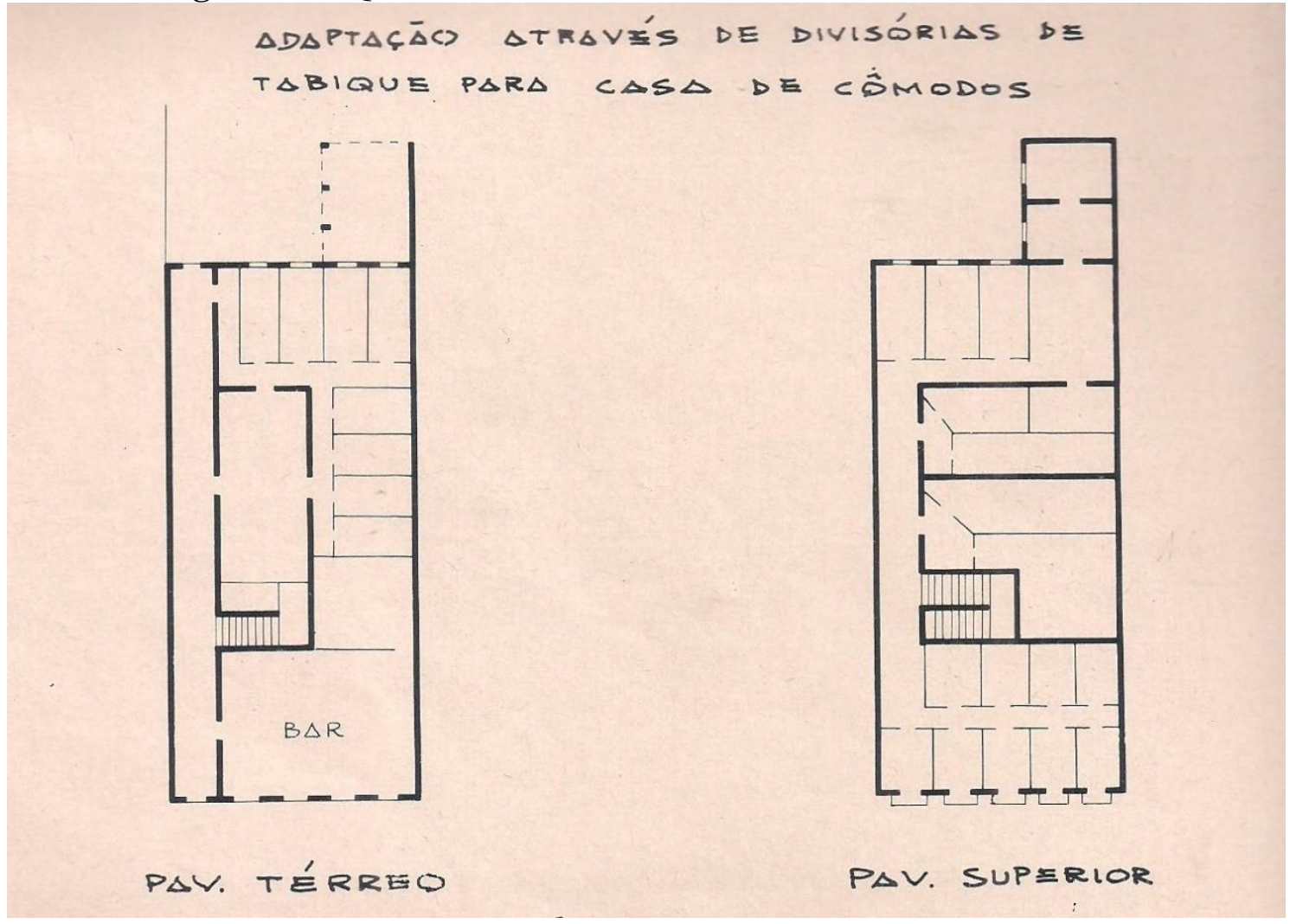

Fonte: Espinheira, 1971: 17.

Podemos afirmar, a partir das memórias das nossas interlocutoras, que elas não habitavam seus quartos, limitando-se a entrar e sair deles, mudando-se de um a outro constantemente. Habitavam, isso sim, as ruas que, em conjunto, formavam o bairro. $\mathrm{Na}$ medida em que suas memórias são de espaços habitados, elas mal falam dos quartos.

O que se desprende dessa experiência rememorada é que é possível viver sem habitar casas e, portanto, sem contrapor casa e rua. É possível, igualmente, contrariar a ideia - ocidental, muito recente e bastante burguesa - segundo a qual "todo espaço 
realmente habitado traz a essência da noção de casa" (Bachelard, 1998: 24). Na Europa, nos lembra Witold Rybczynski (1996), a casa medieval era um lugar público, não privado: vivia cheia de gente, geralmente em um único cômodo, servindo para morar e trabalhar. Nelas, "até dormir era uma atividade comunitária", pois várias pessoas dormiam em uma única cama ou colchão (Rybczynski, 1996: 41). Se, para muitos, no velho continente, até entrado o século XVIII, as casas não passavam de "abrigos para dormir" (idem: 37), para os setores populares de Salvador, em sua maior parte descendentes de escravizados, esta função se manteve intacta até muito recentemente conforme o silêncio de nossas interlocutoras nos permite pensar.

Para esta população, as habitações como espaços públicos se remontam aos tempos da escravidão, em que os escravos dormiam juntos nas senzalas ou térreos, sótãos ou porões das casas dos senhores. Na condição de escravos de ganho ou de libertos, passaram a dormir nas "lojas", nome dado às habitações do andar térreo dos casarões subdivididos (Costa, 1989: 115). As lojas consistiam em uma só grande sala, com pouca ventilação, sem separações em quartos, onde escravos e libertos dormiam em esteiras estendidas no chão (idem: 200). No século XX, todos os pavimentos de sobrados e casarões foram subdivididos em pequenos quartos, onde a população pobre da cidade passou a morar até a década de 1990, momento a partir do qual os imóveis do CHS foram esvaziados e reformados, para serem transformados, em sua grade maioria, em comércios, restaurantes e hotéis, ou, no caso da $7^{\mathrm{a}}$ etapa, em apartamentos chamados de "casas". Podemos considerar estes quartos como sendo públicos na medida em que os tapumes que os separavam eram tão finos e cobriam apenas a metade do pé direito que se podia ouvir e cheirar tudo o que se passava ao lado, resultando a privacidade praticamente impossível.

Enquanto estes quartos não são lembrados pelas nossas interlocutoras, eles ocuparam o centro da atenção de muitos intelectuais que, em épocas diversas, retrataram o CHS. Em contraste com as moradoras, o interesse destes se centrava na materialidade dos imóveis degradados e na habitação, não na rua nem nas relações que se teciam entre as pessoas que as habitavam. O mais dramático é que, mediante uma lógica perversa, o foco na materialidade degradada acabava se confundindo com uma visão das relações sociais sendo igualmente degradadas. No centro de Salvador da década de 1920 retratada em Suor, Jorge Amado fez claramente essa associação. Imóveis, pessoas e ambiente conformavam uma unidade: "um mundo fétido, sem higiene e sem moral, com ratos, palavrões e gente" (Amado, 2011: 230). Na década de 1950, Milton Santos descreveu os distritos da Sé e do Passo como uma "uma zona de degradação", "um verdadeiro inferno": 
Salas e quartos demasiadamente pequenos, verdadeiras células, estão separados por paredes de madeira. Nesses cubículos não há luz, nem ar e inexiste higiene. A vida nesses cortiços é um verdadeiro inferno e as diversas famílias que ocupam um mesmo andar se veem obrigadas a se servirem de um único banheiro e de uma só latrina. Escadas estragadas, soalhos furados, paredes sujas, tetos com goteiras formam um quadro comum a toda essa zona de degradação. (Santos, 1959: 166).

Em 1971, Gey Espinheira, sociólogo, chefe do Setor de Planejamento e Pesquisas do que fora naquele tempo a Fundação do Patrimônio Artístico e Cultural da Bahia, escreveu: "O Maciel em toda sua extensão é degradante e prepara para os moradores mais jovens uma educação negativa” (Espinheira, 1971: 50). O isolamento e pobreza dessa comunidade em meio a um ambiente material precário gerava um comportamento "socialmente patológico" (idem: 5) e "divergente" (idem: 45) de seus moradores. O alto número de atividades transgressoras, contravenções e criminalidade verificadas na prostituição, uso e tráfico de entorpecentes, roubos, agressão física e à mão armada (idem: 46) geravam um "quadro dramático" (idem: 3), uma "comunidade degradada" (idem: 3), uma "comunidade anômala" (idem: 5), "um ambiente de doenças, misérias e crimes" (idem: 10).

Décadas depois, o ambiente insalubre é também ressaltado na descrição da área da $7^{\mathrm{a}}$ etapa feita pelo sociólogo José Maurício Bittencourt, na época assessor da Equipe Urbana do Centro de Estudos e Ação Social (CEAS):

(...) Prevalecia na área da $7^{\mathrm{a}}$ etapa o cheiro de esgoto, lixo e mofo que caracterizavam o ambiente nessa área (...), os ratos e pombos também eram personagens sempre presentes nas visitas feitas (...). Durante a noite somava-se ainda a esse ambiente insalubre a falta de iluminação pública, tornando o ambiente ainda mais inóspito. (Bittencourt, 2015: 20; 21)

Entretanto, este autor consegue admitir que o ambiente "inóspito" era capaz de criar histórias familiares exitosas e relações sociais comunitárias:

(...) $[\mathrm{Na}$ área] existem pessoas trabalhadoras, famílias inteiras criadas em ambientes insalubres e violentos, mas que conseguiram formar seus filhos em universidades, exército, cursos técnicos, mesmo na adversidade. Por outro lado, ali também se efetivam formas de sociabilidade de convivência comunitárias (...). (Bittencourt, 2015: 20: 23)

O ambiente inóspito e a precariedade das construções não é trazido à tona pelas memórias das habitantes da 28. Sem negar essas dificuldades, parece-me que se trata de 
uma questão de prioridade: enquanto uns estão interessados no habitat, na materialidade das habitações, outros enfatizam o habitar, as relações que compõem o bairro.

À visão sociológica centrada na fusão entre a degradação dos imóveis e a degradação da vida neles soma-se uma outra, igualmente contrária à visão do bairro contida nas memórias das interlocutoras da 28: a de que esse bairro - como todo o CHS antes da reforma - era um conglomerado de ruínas. A área era enxergada como um monte de imóveis coloniais formando um conjunto arquitetônico único, porém, prestes a desabar. O ânimo daqueles que detinham este ponto de vista era de lamentação ou tristeza, tamanho o abandono e a falta de conservação por parte dos órgãos patrimoniais. Esta "visão elitista das ruínas" (Gordillo, 2018), orquestrada pelos setores ligados ao patrimônio e à indústria cultural, aparecia constantemente nos jornais, promovendo uma opinião pública a favor da reforma.

Na visão local da 28, entretanto, não havia ruínas no bairro. Havia imóveis velhos, sempre consertados e adaptados para, de alguma forma, proteger seus moradores da intempérie, para que eles pudessem "deitar a cabeça”. A casa de Dona Kátia, em finais da década de 1990, descrita por Collins (2015: 141, tradução nossa), pode exemplificar estes consertos precários: “A casa é construída sobre as tábuas apodrecidas de um casarão do século XVIII, com o telhado desabado e vigas danificadas pelo fogo envoltas em papelão úmido. Estes produziam um piso flutuante que não desmoronava desde que pisado perto das vigas".

Em seu fantástico trabalho sobre a diversidade de escombros que se acumulam na região de Salta, no Norte argentino, Gastón Gordillo conta como um habitante do lugar, intrigado diante de sua incessante procura por ruínas, perguntou-lhe certa vez: "Você chama de ruínas a essas casas velhas, né?" (Gordillo, 2018: 21, tradução nossa). Nesse momento, o antropólogo entendeu que "ruína" era uma palavra que não podia ser parte do vocabulário do habitante, pois o espaço habitado não comporta abstrações. O que para uns é denominado de igreja abandonada, casa velha ou povoado desabitado, para o estranho é tudo "ruína". Nesse sentido, ruína é uma nomenclatura própria do capitalismo, que tudo abstrai, que "reduz a textura sensorial e multifacetada dos lugares a abstrações" (idem: 22). Desde outra perspectiva, ela é fruto da modernidade, que concebe o tempo como se fosse uma linha na qual seria possível fazer cortes, sendo as ruínas os escombros escolhidos para se manterem enquanto tais, mumificados, congelados, fetichizados como sendo de um tempo supostamente superado. 
O que para os amantes do patrimônio constituíam ruínas a serem veneradas, para outros eram construções sempre passíveis de serem reutilizadas de forma terrena, mundana, pagã. As ruínas só podem ser tais para aqueles que mantêm um distanciamento afetivo e um estranhamento físico em relação a um lugar. Para quem habita o lugar, que interage nele e com ele cotidianamente, os espaços, velhos ou novos, têm sempre texturas, usos e significados diferenciados, daí terem nomes particulares. Os escombros estão sempre imbrincados no e com o espaço habitado, "não são matéria morta, inerte e fechada em si mesma" (idem: 36).

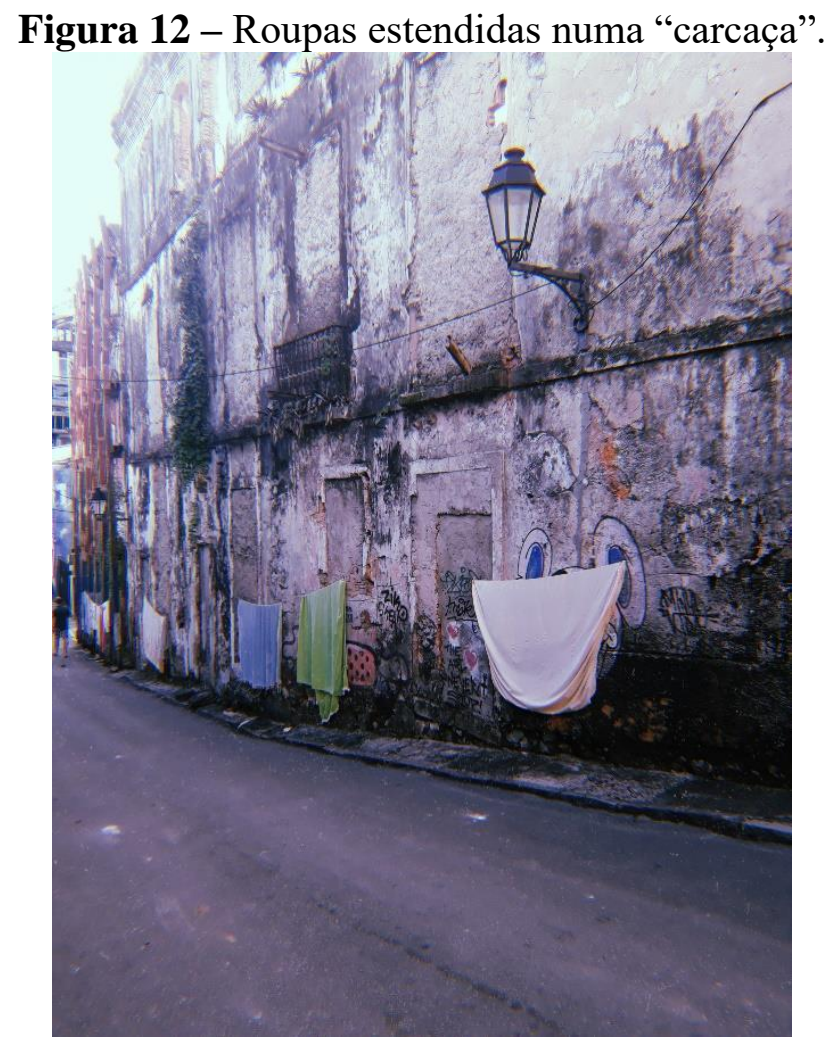

Fonte: ACCS/Panoramas Urbanos.

Quando não restava ou resta quase mais nada dos velhos casarões, os habitantes se referem a eles como "carcaças", isto é, esqueletos que sustentaram algo que não existe mais. Não usam a palavra ruína, pois não há nenhum sentimento de veneração por eles; pelo contrário, mantêm com eles uma relação absolutamente mundana: penduram roupas, usam sua sombra, se encostam para conversar ou simplesmente jogam lixo; outros, fazem uso de drogas nelas.

$\mathrm{Na}$ lógica do habitar, o esqueleto pode sempre sustentar algo. Antes da reforma, quando não havia mais jeito para segurar as paredes internas e estas desabavam, as paredes 
externas ainda podiam servir para separar a rua das diminutas casas de porta-e-janela improvisadas com tábuas, paus e tetos de zinco que proliferavam nos terrenos que passavam a surgir (cf. Figura 13).

Figura 13 - Carcaça habitada na Rua Saldanha da Gama, n. 18, em meados da

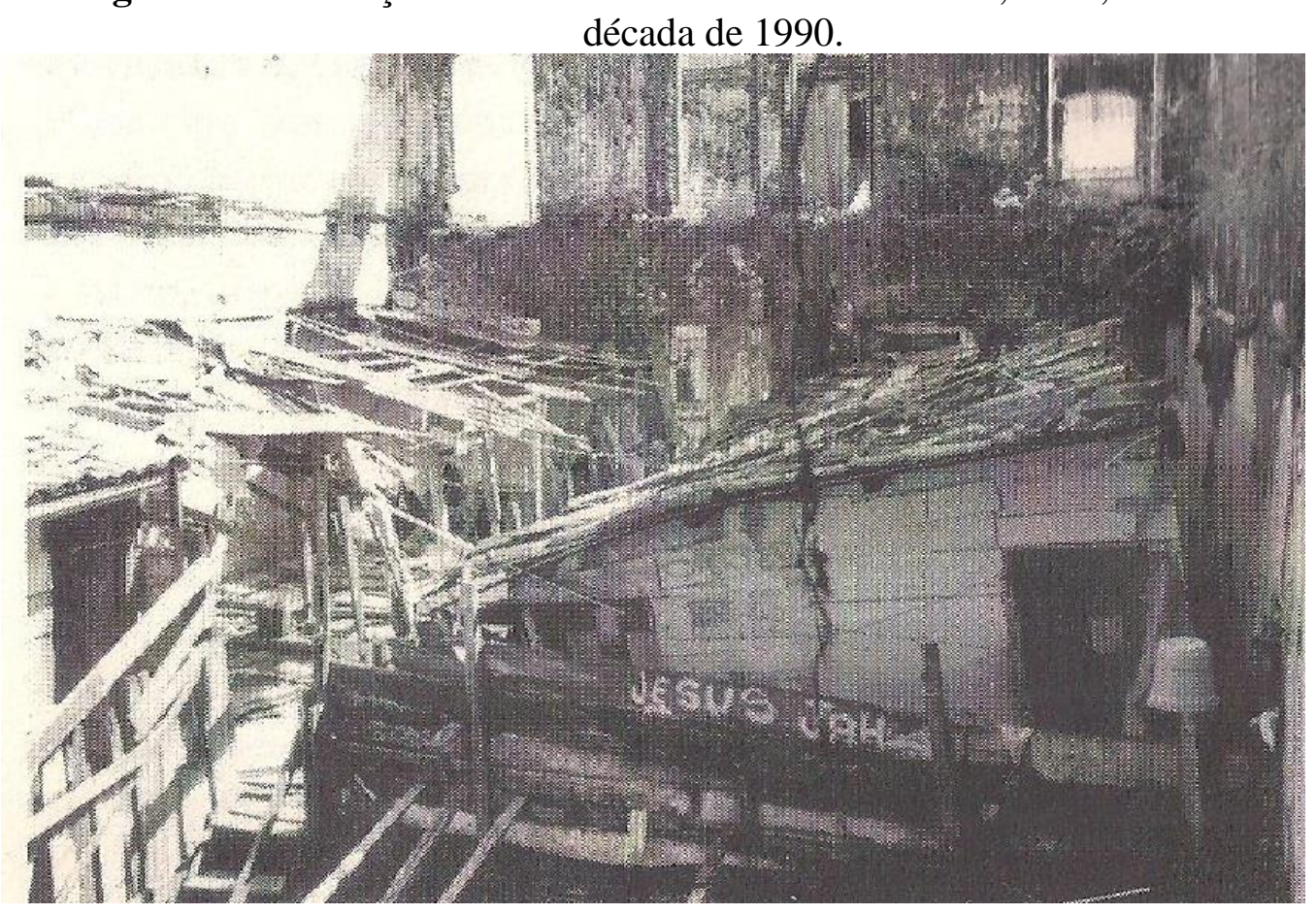

Fonte: Collins, 2015: 2.

\section{A 28 reformada: bairro em ruínas}

Hoje, não é mais possível fazer isso. Os órgãos do patrimônio não permitem. Assim como não permitem o comércio que, até antes da reforma, dava vida ao bairro. Nem o comércio de estabelecimentos, nem o comércio nas portas das casas, tão lembrado pelas mulheres da 28: "Era casa em cima e movimento embaixo" (Sandra); "O que botava na porta vendia" (Rita); "Todas as ruas tinham bares (...). Todos os bares, quase todos os bares, vendiam comida" (Sandra); "As pessoas tiravam seu sustento sem sair do bairro: lavavam roupa, cuidavam de crianças, colocavam suas guias na porta de casa, vendiam cachorro quente, se prostituíam” (Eugênia).

Sandra tem consciência da antiguidade dessa forma de sobrevivência quando afirma que "nossa cultura sempre foi mercar". Com efeito, em Salvador, durante séculos, as mulheres africanas e suas descendentes reinaram nas ruas, principalmente vendendo comida: 
Segundo aquele censo de Santana de 1849, entre as libertas que negociavam a maioria afirmou "mercadejar diversos gêneros". As que foram mais específicas declararam vender mingau, acaçá, aberém, frutas, verduras, feijão, arroz, milho, pão, peixe. Praticamente monopolizavam o pequeno comércio, ocupando as feiras a céu aberto ou pregoando de porta em porta. (Reis, 2019: 95).

Sabedoras da importância do comércio para a vida do bairro e a sobrevivência das famílias, a AMACH se assegurou, na Cláusula 8 do TAC, da manutenção dos pontos comerciais e sua localização:

\begin{abstract}
Os pontos comerciais existentes na área da $7^{\mathrm{a}}$ etapa poderão ser transferidos, temporariamente, caso haja necessidade, para outro local do Centro Histórico de Salvador, durante a execução das obras. Se o ponto comercial não puder retornar ao imóvel onde estava instalado, o caso será submetido ao Comitê, garantida a sua permanência no Centro Histórico de Salvador, em outro imóvel da área da $7^{\mathrm{a}}$ etapa, se assim deseja o proprietário. (apud Figueiredo et al., 2017: 26).
\end{abstract}

Entretanto, apenas inicialmente os termos de posse de imóvel a título precário permitiram "associar o uso residencial com atividades de geração de renda para a sobrevivência da família, apoiando, portanto, as alternativas de trabalho e renda construídas pelo morador" (Figueiredo et al., 2017: 18). Posteriormente, contudo, o uso misto foi caçado. Hoje, 15 anos depois de assinado o TAC, ainda muitos aguardam reaver seus antigos pontos, sendo que um grande número sequer conseguiu tê-los em outros locais do CHS:

Da mesma forma que era com a moradia também seria com os pontos comerciais. Remanejado durante as obras, com retorno garantido. Isso não está acontecendo, não sei se vai acontecer porque a CONDER [Companhia de Desenvolvimento Urbano do Estado da Bahia] está chamando as famílias que estão em ponto comercial pago pela CONDER dizendo que não haverá mais pontos comerciais (...). (Jecilda Mello, 2016, apud Figueiredo et al., 2017: 107)

Conforme documentado pelo historiador João Reis em seu livro Ganhadeiros, o século XIX foi um período no qual, mediante diversas leis, posturas e sanções policiais, tentou-se controlar o uso do espaço público por parte desse segmento de trabalhadores “considerado indisciplinado" (Reis, 2019: 257) e "classe perigosa" (idem: 259). O caráter coletivo de seu trabalho, suas redes e particular junção de serviço e lazer, assim como a suposta algazarra que promoviam, sujeira e desordens, foram os principais motivos e argumentos que levaram os poderes públicos da época a perseguir, de diversas maneiras, os ganhadeiros e as mulheres que mercavam de forma ambulante. À perseguição, eles e 
elas responderam com resistências igualmente variadas: "Organizar o ganho e disciplinar o ganhador não eram tarefas fáceis, fosse ele africano ou nacional, escravizado, liberto ou livre" (idem: 255). Entretanto, em finais do século XX, o fechamento de seus pontos comerciais e a impossibilidade de mercar nas portas de seus imóveis, em nome da reforma do patrimônio, foi o golpe derradeiro, pelo menos na área da 28.

Sem gente e sem comércio, as ruas do bairro atual são descritas por nossas interlocutoras como a morte, o cemitério, o deserto onde nada floresce: "Ficou muito deserto. Sumiu o povo todo, você conta de dedo as pessoas" (Edna); "Aqui está muito vazio, parece um cemitério" (Rita); "Hoje está muito deserto, não se vê mais crianças, não se vê mais famílias, não se vê mais uma guia para vender, tirar o sustento" (Eugênia); "Hoje está tudo morto" (Helena); "Aqui parece uma planta morrendo sem você conseguir salvar" (Zenilda).

A reforma transformou o bairro em um cemitério. Virou o que se queria recuperar: ruínas. Imóveis sem vida, vigiados para que nada neles seja alterado. A política do Governo do Estado da Bahia criou morte onde havia vida. Fez um conjunto de casas reformadas onde antes havia um bairro. É o Antropoceno na cidade: um mundo de paisagens arruinadas ou "perturbadas", sem habitabilidade, um mundo de ruínas (Tsing, 2019).

Mas a história do capitalismo não é apenas a história da produção de espaços novos criando sucessivos escombros. É também a produção de vida nos escombros. Se a produção do espaço se faz da destruição de outros espaços, os escombros deixados são sucessivamente ocupados pelos esquecidos e subjugados do sistema. A história do CHS é essa: espaço de índios que foi usurpado por portugueses, cujos africanos escravizados construíram casarões e passaram a morar em seus porões e lojas. Descendentes desses portugueses, séculos depois, construíram novas casas em outros espaços, usurpados de outras pessoas, e os descendentes dos africanos escravizados passaram a ocupar todos os andares dos velhos casarões. Da mesma forma, no quilombo Dom João, em São Francisco do Conde, no Recôncavo da Bahia, 80 famílias criaram um berçário de guaiamuns nos escombros que deixaram o açúcar do século XIX e o petróleo de meados do século seguinte. $\mathrm{O}$ ancoradouro, a caldeira de petróleo, a chaminé da usina e outros objetos abandonados se tornaram seu espaço habitado (Buti, 2019).

"Se quisermos viver, devemos aprender a ocupar até os espaços mais degradados da vida na Terra", escreveu Anna Tsing (2019: 87). No Antropoceno, conclui a antropóloga, "precisamos explorar seus pedaços que ainda promovem a vida. As ruínas agora são nossos 
jardins" (Tsing, 2018: 381). Assim, as antigas moradoras da 28 resistem, aprendendo duramente a viver em condições adversas, nos escombros - sem gente, sem comércio, sem vida - do que fora o seu bairro animado. Como em muitos espaços semelhantes, as ruínas da 28 deverão ver aparecer "ressurgências", isto é, "o trabalho de muitos organismos negociando suas diferenças para forjar ajuntamentos multiespécies em meio aos distúrbios de paisagens arruinadas" (Buti, 2019: 10). Sabedoras que terão de fundar um novo espaço por cima das ruínas, as mulheres da AMACH já têm nome para ele: bairro de São Dâmaso. Resta o enorme desafio de lhe dar vida.

\section{Referências}

AMADO, Jorge. Suor. São Paulo, Companhia das Letras, 2011. [1934]

AUGÉ, Marc. El tiempo en ruinas. Barcelona, Gedisa, 2008.

BACHELARD, Gaston. A poética do espaço. São Paulo, Martins Fontes, 1998.

BITTENCOURT, José Maurício Carneiro Daltro. Luta e resistência dos moradores pelo direito à moradia em áreas de patrimônio cultural: a formação de uma esfera pública. Salvador, Edufba, 2015.

BUTI, Rafael Palermo. O "Gaiamum Petroleiro", o "Meio Ambiente", o "Quilombo" e o "Manquintal": notas sobre (des)fazer mundos nas paisagens de mangue no Recôncavo da Bahia. Anais da VII Reunião de Antropologia da Ciência e Tecnologia, v. 4 n. 4, 2019. Disponível em: <https://ocs.ige.unicamp.br/ojs/react/article/view/2703>. Acesso em: 5 jul. 2020.

CASTRO, José. De morador a mendigo do Pelô. A Tarde, Salvador, p. 3, 29 jan. de 2004.

COLLINS, John F. Revolt of the saints. Memory and redemption in the twiligth of brazilian racial democracy. Nova York, Duke University Press, 2015.

COSTA, Ana de Lourdes Ribeiro da. Ekabó! Trabalho escravo, condições de moradia e reordenamento urbano em Salvador no século XIX. Dissertação (Mestrado em Arquitetura). Salvador, UFBA, 1989.

DA MATTA, Roberto. A casa e a rua. Espaço, cidadania, mulher e morte no Brasil. São Paulo, Brasiliense, 1985.

DA MATTA, Roberto. O Brasil como morada. Apresentação. In: FREYRE, Gilberto. Sobrados e mucambos. Decadência do patriarcado rural e desenvolvimento do urbano. 15. ed. São Paulo, Global, 2004.

DO RIO, João. A alma encantadora das ruas. Organização de Raul Antelo. São Paulo, Companhia das Letras, 2008. 
ESPINHEIRA, Carlos G. D’Andrea. Comunidade do Maciel. Salvador, Fundação do Patrimônio Artístico e Cultural da Bahia, 1971.

FIGUEIREDO, Glória Cecília dos Santos; MELLO, Jecilda Maria da Cruz; BOULLOSA, Rosana de Freitas; VASCONCELLOS, Emanuel Lins Freire (coord.). Perícia popular no centro histórico de Salvador. Avaliação das condições de vida dos habitantes vulnerabilizados pelo descumprimento da TAC da $7^{a}$ etapa. Dossiê coletivo. Relatório da Ação Curricular em Comunidade e em Sociedade (ACCS). Salvador, UFBA, 2017. (inédito)

FREYRE, Gilberto. Sobrados e mucambos. Decadência do patriarcado rural e desenvolvimento do urbano. 15. ed. São Paulo, Global, 2004.

GORDENSTEIN, Samuel Lira. De sobrado a terreiro. A construção de um Candomblé na Salvador oitocentista. Tese (Doutorado em Antropologia). Salvador, UFBA, 2014.

GORDILLO, Gastón. Los escombros del progreso. Ciudades perdidas, estaciones abandonadas y deflorestación sojera en el norte argentino. Buenos Aires, Siglo XXI, 2018.

HALBWACHS, Maurice. A memória coletiva. São Paulo, Vértice, 1990. [1950]

JACOBS, Jane. Muerte y vida de las grandes ciudades. 2. ed. Madri, Pensínsula, 1973.

LE GOFF, Jacques. Histoire et mémoire. Paris, Gallimard, 1988.

MALHEIRO, Luana Silva Bastos. Entre sacizeiro, usuário e patrão: Um estudo etnográfico sobre consumidores de crack no Centro Histórico de Salvador. In: MACRAE, Edward; TAVARES, Luís Antônio; NUÑEZ, Maria Eugênia (org.). Crack: contextos, padrões e propósitos de uso. Salvador, Centro de Estudos e Terapia do Abuso de Drogas; Edufba, 2013.

MONTOYA URIARTE, Urpi. Cronistas da cidade e cultura urbana em inícios do século XX. Os costumbristas de Lima e João do Rio. Ponto Urbe, 9, p. 1-18, 2011. Disponível em: 〈https://journals.openedition.org/pontourbe/254>.

MONTOYA URIARTE, Urpi. Entra em beco, sai em beco. Formas de habitar o centro, Salvador e Lisboa. Salvador, Edufba, 2019.

PINA-CABRAL, João de; SILVA, Vanda Aparecida da. Gente livre. Consideração e pessoa no Baixo Sul da Bahia. São Paulo, Terceiro Nome, 2013.

REIS, João José. Ganhadores. A greve negra de 1857 na Bahia. São Paulo, Companhia das Letras, 2019.

RYBCZYNSKI, Witold. Casa. Pequena história de uma ideia. Rio de Janeiro, Record, 1996.

SANTOS, Carlos Nelson dos et al. Quando a rua vira casa. A apropriação de espaços de uso coletivo em um centro de bairro. 2. ed. revista e atualizada. Rio de Janeiro, IBAM/FINEP, 1981. 
SANTOS, Milton. O centro da cidade do Salvador. Estudo de geografia urbana. Salvador, UFBA; Progresso, 1959.

SARLO, Beatriz. Tiempo pasado. Cultura de la memoria y giro subjetivo. Una discusión. Buenos Aires, Siglo XXI, 2007.

TSING, Anna Lowenhaupt. Paisagens arruinadas (e a delicada arte de coletar cogumelos). Cadernos do Lepaarq, v. XV, n. 30, p. 366-382, jul./dez. 2018.

TSING, Anna Lowenhaupt. Viver nas ruínas: paisagens multiespécies no Antropoceno. Brasília, IEB Mil Folhas, 2019.

VIVEIROS DE CASTRO, Eduardo. O nativo relativo. Mana, Rio de Janeiro, v. 8, n. 1, abr. 2002.

Data de submissão: 8 de janeiro de 2021

Data de publicação: 20 de dezembro de 2021 